\title{
OMI total bromine monoxide (OMBRO) data product: algorithm, retrieval and measurement comparisons
}

\author{
Raid M. Suleiman ${ }^{1}$, Kelly Chance ${ }^{1}$, Xiong Liu ${ }^{1}$, Gonzalo González Abad ${ }^{1}$, Thomas P. Kurosu ${ }^{2}$ Francois Hendrick $^{3}$, \\ and Nicolas Theys ${ }^{3}$ \\ ${ }^{1}$ Harvard-Smithsonian Center for Astrophysics, Cambridge, MA, USA \\ ${ }^{2}$ Jet Propulsion Laboratory, California Institute of Technology, Pasadena, CA, USA \\ ${ }^{3}$ Royal Belgian Institute for Space Aeronomy, Brussels, Belgium
}

Correspondence: Raid M. Suleiman (rsuleiman@cfa.harvard.edu)

Received: 3 January 2018 - Discussion started: 30 January 2018

Revised: 11 March 2019 - Accepted: 19 March 2019 - Published: 4 April 2019

\begin{abstract}
This paper presents the retrieval algorithm for the operational Ozone Monitoring Instrument (OMI) total bromine monoxide $(\mathrm{BrO})$ data product (OMBRO) developed at the Smithsonian Astrophysical Observatory (SAO) and shows comparisons with correlative measurements and retrieval results. The algorithm is based on direct nonlinear least squares fitting of radiances from the spectral range $319.0-347.5 \mathrm{~nm}$. Radiances are modeled from the solar irradiance, attenuated by contributions from $\mathrm{BrO}$ and interfering gases, and including rotational Raman scattering, additive and multiplicative closure polynomials, correction for Nyquist undersampling and the average fitting residual spectrum. The retrieval uses albedo- and wavelength-dependent air mass factors (AMFs), which have been pre-computed using a single mostly stratospheric $\mathrm{BrO}$ profile. The $\mathrm{BrO}$ cross sections are multiplied by the wavelength-dependent AMFs before fitting so that the vertical column densities (VCDs) are retrieved directly. The fitting uncertainties of BrO VCDs typically vary between 4 and $7 \times 10^{12}$ molecules $\mathrm{cm}^{-2}(\sim 10 \%-$ $20 \%$ of the measured $\mathrm{BrO}$ VCDs). Additional fitting uncertainties can be caused by the interferences from $\mathrm{O}_{2}-\mathrm{O}_{2}$ and $\mathrm{H}_{2} \mathrm{CO}$ and their correlation with $\mathrm{BrO}$. AMF uncertainties are estimated to be around $10 \%$ when the single stratosphericonly $\mathrm{BrO}$ profile is used. However, under conditions of high tropospheric concentrations, AMF errors due to this assumption of profile can be as high as $50 \%$.
\end{abstract}

The retrievals agree well with GOME-2 observations at simultaneous nadir overpasses and with ground-based zenith-sky measurements at Harestua, Norway, with mean biases less than $-0.22 \pm 1.13 \times 10^{13}$ and $0.12 \pm 0.76 \times$
$10^{13}$ molecules $\mathrm{cm}^{-2}$, respectively. Global distribution and seasonal variation of OMI BrO are generally consistent with previous satellite observations. Finally, we confirm the capacity of OMBRO retrievals to observe enhancements of $\mathrm{BrO}$ over the US Great Salt Lake despite the current retrieval setup considering a stratospheric profile in the AMF calculations. OMBRO retrievals also show significant $\mathrm{BrO}$ enhancements from the eruption of the Eyjafjallajökull volcano, although the $\mathrm{BrO}$ retrievals are affected under high $\mathrm{SO}_{2}$ loading conditions by the sub-optimum choice of $\mathrm{SO}_{2}$ cross sections.

\section{Introduction}

Bromine monoxide $(\mathrm{BrO})$ is a halogen oxide, predominantly located in the stratosphere and upper troposphere, where, like chlorine monoxide $(\mathrm{ClO})$, it is a catalytic element in the destruction of stratospheric ozone (von Glasow et al., 2004; Salawitch et al., 2005) but with higher efficiency per molecule. Sources of tropospheric $\mathrm{BrO}$ include bromine release ("explosions") during the polar spring (Hausmann and Platt, 1994; Hollwedel et al., 2004; Simpson et al., 2007; Begoin et al., 2010; Salawitch et al., 2010; Abbatt et al., 2012; Blechschmidt et al., 2016), volcanic eruptions (Bobrowski et al., 2003; Chance, 2006; Theys et al., 2009), salt lakes (Hebestreit et al., 1999; Hörmann et al., 2016) and stratospheric transport (Salawitch et al., 2010). Global BrO measurements from space were first proposed for the Scanning Imaging Absorption Spectrometer for Atmospheric Cartography (SCIA- 
MACHY) instrument (Chance et al., 1991) and were first demonstrated with Global Ozone Monitoring Experiment (GOME-1) measurements (Chance, 1998; Platt and Wagner, 1998; Richter et al., 1998; Hegels et al., 1998), and since with SCIAMACHY nadir (Kühl et al., 2008), Global Ozone Monitoring Experiment 2 (GOME-2) measurements (Theys et al., 2011; Toyota et al., 2011) and TROPOMI (Seo et al., 2018). Initial observations of $\mathrm{BrO}$ by the Ozone Monitoring Instrument (OMI) were first reported by Kurosu et al. (2004). Polar spring $\mathrm{BrO}$ enhancements are known to be associated with boundary layer $\mathrm{O}_{3}$ depletion (Hausmann and Platt, 1994; von Glasow et al., 2004; Salawitch et al., 2005, 2010; Simpson et al., 2007; Abbatt et al., 2012). OMI measurements of $\mathrm{BrO}$ have been used together with chemical and dynamical modeling to investigate stratospheric versus tropospheric enhancements of atmospheric $\mathrm{BrO}$ at high northern latitudes (Salawitch et al., 2010). OMI BrO retrieval using the Differential Optical Absorption Spectroscopy (DOAS) method has been used to study the seasonal variations of tropospheric bromine monoxide over the Rann of Kutch salt marsh (Hörmann et al., 2016). The Arctic Research of the Composition of the Troposphere from Aircraft and Satellites (ARCTAS) campaign (Choi et al., 2012) found consistency between $\mathrm{BrO}$ column densities calculated from Chemical Ionization Mass Spectrometer (CIMS) measurements with the tropospheric $\mathrm{BrO}$ columns derived from OMI using our operational retrieval algorithm. $\mathrm{BrO}$ has been observed from the ground in Harestua, Norway (Hendrick et al., 2007); Lauder, New Zealand (Schofield et al., 2004a, b); Antarctica (Schofield et al., 2006); Utqiagivik (formerly Barrow), Alaska (Liao et al., 2011, 2012; Frieß et al., 2011; Sihler et al., 2012; Peterson et al., 2016); Eureka, Canada (Zhao et al., 2015); Summit, Greenland (Stutz et al., 2011); and the Arctic Ocean (Burd et al., 2017).

Enhancement of $\mathrm{BrO}$ in the vicinity of salt lakes like the Dead Sea and the Great Salt Lake has been observed from ground-based measurements (Hebestreit et al., 1999; Matveev et al., 2001; Stutz et al., 2002; Tas et al., 2005; Holla et al., 2015). The active bromine compound release is due to the reaction between atmospheric oxidants with salt reservoirs. Satellite observation of salt lake $\mathrm{BrO}$ was first reported over the Great Salt Lake and the Dead Sea by OMI (Chance, 2006; Hörmann et al., 2016). Seasonal variations of tropospheric BrO over the Rann of Kutch salt marsh have been observed using OMI from an independent research $\mathrm{BrO}$ product (Hörmann et al., 2016). Bobrowski et al. (2003) made the first ground-based observations of $\mathrm{BrO}$ and $\mathrm{SO}_{2}$ abundances in the plume of the Soufrière Hills volcano (Montserrat) using multi-axis DOAS (MAX-DOAS). $\mathrm{BrO}$ and $\mathrm{SO}_{2}$ abundances as functions of the distance from the source were measured by MAX-DOAS in the volcanic plumes of Mt. Etna in Sicily, Italy, and Villarica in Chile (Bobrowski et al., 2007). The $\mathrm{BrO} / \mathrm{SO}_{2}$ ratio in the plume of Nyiragongo and Etna was also studied (Bobrowski et al., 2015). The first volcanic $\mathrm{BrO}$ measured from space was from the Am- brym volcano, measured by OMI (Chance, 2006). Theys et al. (2009) reported on GOME-2 detection of volcanic $\mathrm{BrO}$ emission after the Kasatochi eruption. Hörmann et al. (2013) examined GOME-2 observations of $\mathrm{BrO}$ slant column densities (SCDs) in the vicinity of volcanic plumes; the study showed clear enhancements of $\mathrm{BrO}$ in $\sim$ one-quarter of the volcanos and revealed large spatial differences in $\mathrm{BrO} / \mathrm{SO}_{2}$ ratios.

The purpose of this paper is to describe the OMI BrO operational algorithm and the data product, compare it with ground-based and other satellite measurements and analyze its spatiotemporal characteristics. This paper is organized as follows: Sect. 2 describes the OMI instrument and the data product. Section 3 gives a detailed description of the operational algorithm including algorithm and product history, spectral fitting, air mass factor (AMF) calculations, destriping and fitting uncertainties. Section 4 presents results and discussion including comparison with GOME-2 and groundbased zenith-sky measurements at Harestua, Norway, and global distribution, seasonality and enhanced $\mathrm{BrO}$ from the US Great Salt Lake and Iceland's Eyjafjallajökull volcano. Section 5 concludes this study.

\section{OMI instrument and OMBRO data product}

\subsection{OMI instrument}

OMI (Levelt et al., 2006) was launched on the NASA Earth Observing System (EOS) Aura satellite into a sunsynchronous orbit on 15 July 2004. It is a push-broom imaging spectrometer that observes solar backscattered radiation in the visible and ultraviolet from 270 to $500 \mathrm{~nm}$ in three channels (UV1: $270-310 \mathrm{~nm}$, UV2: $310-365 \mathrm{~nm}$, visible: $350-500 \mathrm{~nm}$ ) at a spectral resolution of $0.42-0.63 \mathrm{~nm}$ and spatial resolution in the normal (global sampling) mode ranging from $13 \mathrm{~km} \times 24 \mathrm{~km}$ at direct nadir to about $28 \mathrm{~km} \times 150 \mathrm{~km}$ at the swath edges. The global mode (GM) has 60 ground pixels with a total cross-track swath of $2600 \mathrm{~km}$.

Since June 2007, certain cross-track positions of OMI data have been affected by the row anomaly (http://projects.knmi. nl/omi/research/product/rowanomaly-background.php, last access: 20 November 2017): some loose thermal insulating material likely appeared in front of the instrument's entrance slit, which can block and scatter the light, thus causing errors in level $1 \mathrm{~b}$ data and subsequently the level 2 retrievals (Kroon et al., 2011). Initially, the row anomaly only affected a few positions, and the effect was small. But since January 2009, the anomaly has become more serious, spreading to $\sim$ onethird of the positions, and retrievals at those positions are not recommended for scientific use. A flagging field has been introduced in the OMI level $1 \mathrm{~b}$ data to indicate whether an OMI pixel is affected by this instrument anomaly. 
OMI measures $\mathrm{O}_{3}$ and other trace gases, aerosols, clouds and surface properties. Products developed at the SAO include operational $\mathrm{BrO}$, chlorine dioxide (OClO), and formaldehyde $\left(\mathrm{H}_{2} \mathrm{CO}\right.$; González Abad et al., 2015) that are archived at NASA Goddard Earth Sciences (GES) Data and Information Services Center (DISC) and offline ("preoperational") $\mathrm{O}_{3}$ profile and tropospheric $\mathrm{O}_{3}$ (Liu et al., 2010; Huang et al., 2017, 2018), glyoxal $\left(\mathrm{C}_{2} \mathrm{H}_{2} \mathrm{O}_{2}\right)$ (Chan Miller et al., 2014, 2016) and water vapor $\left(\mathrm{H}_{2} \mathrm{O}\right)$ (Wang et al., 2014, 2016) that are available at the Aura Validation Data Center (AVDC). All the products except for the $\mathrm{O}_{3}$ profile product are produced using nonlinear least squares (NLLS) fitting methods based on those previously developed at the SAO for the analysis of measurements from the GOME (now GOME-1) (Chance, 1998; Chance et al., 2000) and SCIAMACHY instruments (Burrows and Chance, 1991; Chance et al., 1991; Martin et al., 2006).

\subsection{OMBRO data product}

The current operational BrO product, OMBRO version 3, contains $\mathrm{BrO}$ vertical column densities (VCDs), slant column densities (SCDs), effective air mass factors (AMFs) and ancillary information retrieved from calibrated OMI radiance and irradiance spectra. Each $\mathrm{BrO}$ product file contains a single orbit of data, from pole to pole, for the sunlit portion of the orbit. The data product from 26 August 2004 through the present is available at GES DISC. Data used in this study cover the period from 1 January 2005 to 31 December 2014.

\section{Retrieval algorithm}

\subsection{Algorithm and product history}

OMBRO Version 1.0 was released on 1 February 2007, based on a spectral fitting window of $338-357 \mathrm{~nm}$. Version 2.0 was released on 13 April 2008. It included major adjustments for Collection 3 level $1 \mathrm{~b}$ data, improved destriping measures, a change of the fitting window to 340$357.5 \mathrm{~nm}$, improvements to radiance wavelength calibration, and several improvements for processing near-real-time data. In both Version 1 and 2, total BrO VCDs were retrieved in two steps: first performing spectral fitting using the basic optical absorption spectroscopy (BOAS) method to derive $\mathrm{SCD}$ from OMI radiance spectra and then converting from SCDs to VCDs by dividing AMFs. This is similar to current $\mathrm{SAO} \mathrm{H}_{2} \mathrm{CO}, \mathrm{H}_{2} \mathrm{O}$ and $\mathrm{C}_{2} \mathrm{H}_{2} \mathrm{O}_{2}$, as mentioned previously. The latest Version 3.0.5, released on 28 April 2011, includes major algorithm changes: the fitting window was moved to $319.0-347.5 \mathrm{~nm}$, and BrO cross sections are multiplied by wavelength-dependent AMFs, which are a function of albedo, before fitting, for a direct retrieval of $\mathrm{BrO}$ VCDs. SCDs are similarly retrieved in a separate step by fitting $\mathrm{BrO}$ cross sections that have not been multiplied with wavelength-dependent AMFs, and an effective AMF =
SCD/VCD is computed. Diagnostic cloud information from the OMCLDO2 product (Acarreta et al., 2004) was added, and the row-anomaly-indicating flags were carried over from the level $1 \mathrm{~b}$ product. We recommend not using pixels affected by the row anomaly despite being processed by the retrieval algorithm.

The current algorithm is described in detail in the rest of this section, with spectral fitting in Sect. 3.2, AMF calculation prior to spectral fitting in Sect. 3.3, post-processing destripping to remove cross-track-dependent biases in Sect. 3.4 and fitting uncertainties and error estimates in Sect. 3.5.

\subsection{Spectral fitting}

Most aspects of the algorithm physics for the direct fitting of radiances by the BOAS method were developed previously at SAO for analysis of GOME and SCIAMACHY satellite spectra (Chance, 1998; Chance et al., 2000; OMI, 2002; Martin et al., 2006) and in the various algorithm descriptions of other SAO OMI products (Wang et al., 2014; Chan Miller et al., 2014; González Abad et al., 2015).

The spectral fitting in the SAO OMI BrO retrieval is based on a Gauss-Newton NLLS fitting procedure, the CERN ELSUNC procedure (Lindström and Wedin, 1987), which provides for bounded NLLS fitting. Processing begins with wavelength calibration for both irradiance and radiance. In each case the wavelength registration for the selected fitting window is determined independently for each cross-track position by cross-correlation of OMI spectra with a high spectral resolution solar irradiance (Caspar and Chance, 1997; Chance, 1998; Chance and Kurucz, 2010) using the preflight instrument slit functions (Dirksen et al., 2006). Radiance wavelength calibration is performed for a representative swath line of radiance measurements (usually in the middle of the orbit) to determine a common wavelength grid for reference spectra.

Following wavelength correction, an undersampling correction spectrum is computed to partially correct for spectral undersampling (lack of Nyquist sampling: Chance, 1998; Slijkhuis et al., 1999; Chance et al., 2005). The calculation of the corrections for the undersampling is accomplished by convolving the preflight slit functions with the highresolution solar spectrum and differencing its fully sampled and undersampled representations (Chance et al., 2005).

To process each OMI orbit, it is split into blocks of 100 swath lines. Spectral fitting is then performed for each block by processing the 60 cross-track pixels included in each swath line sequentially before advancing to the next swath line. The spectra are modeled as follows:

$$
\begin{aligned}
I & =\left\{\left(a I_{0}+\sum_{i} \propto_{i} A_{i}\right) e^{-\sum_{j}\left(\beta_{j} B_{j}\right)}\right. \\
& \left.+\sum_{k} \gamma_{k} C_{k}\right\} \text { Poly }_{\text {scale }}+\text { Poly }_{\text {baseline }}
\end{aligned}
$$


where $I_{0}$ is the solar irradiance (used in our operational $\mathrm{BrO}$ retrieval) or radiance reference measurement, $I$ is the Earthshine radiance (detected at satellite), $a$ is albedo, $\alpha_{i}, \beta_{j}$ and $\gamma_{k}$ are the coefficients to the reference spectra of $A_{i}, B_{j}$ and $C_{k}$ (for example, trace gas cross sections, Ring effect, vibrational Raman, undersampling correction, common mode) of model constituents. To improve cross-track stripe biases (Sect. 3.4), the OMI daily solar irradiance $\left(I_{0}\right)$ is substituted by the first principal component of the solar irradiances measured by OMI between 2005 and 2007 (one for each crosstrack position). The principal component derived between 2005 and 2007 is used to process the entire mission. The reference spectra are derived separately for each cross-track position from original high-resolution cross sections convolved with the corresponding pre-launch OMI slit functions (Dirksen et al., 2006) after correcting for the solar $I_{0}$ effect (Aliwell et al., 2002). Figure 1 shows the trace gas cross sections and Ring spectra used in the current operational algorithm. The black lines are the original high-resolution reference spectra, and the colored lines show the corresponding spectra convolved with the OMI slit function, which are used in the fitting.

For improved numerical stability, radiances and irradiances are divided by their respective averages over the fitting window, renormalizing them to values of $\sim 1$. $\mathrm{BrO}$ is fitted in the spectral window $319.0-347.5 \mathrm{~nm}$, within the UV-2 channel of the OMI instrument. The switch from the previous fitting window of 340-357.5 nm to this shorter and wider fitting window is based on extensive sensitivity analysis following the method described by Vogel et al. (2013). This new fitting window aims at reducing the fitting uncertainty by including more $\mathrm{BrO}$ spectral structures as shown in Fig. 1 and reducing retrieval noise while preserving the stability of the algorithm. An analysis of the retrieval sensitivity to different windows is included in Sect. 3.5.

The rotational Raman scattering (Chance and Spurr, 1997; Chance and Kurucz, 2010) and undersampling correction spectra, $A_{i}$, are first added to the albedo-adjusted solar irradiance $a I_{0}$, with coefficients $\alpha_{i}$ as shown in Eq. (1). Radiances $I$ are then modeled as this quantity attenuated by absorption from $\mathrm{BrO}, \mathrm{O}_{3}, \mathrm{NO}_{2}, \mathrm{H}_{2} \mathrm{CO}$, and $\mathrm{SO}_{2}$, with coefficients $\beta_{j}$ fitted to the reference spectra $B_{j}$ as shown in Eq. (1). A common mode spectrum $C_{k}$, computed online, is added by fitting coefficient $\gamma_{k}$ after the Beer-Lambert law contribution terms. For each cross-track position, an initial fit of all the pixels along the track between $30^{\circ} \mathrm{N}$ and $30^{\circ} \mathrm{S}$ is performed to determine the common mode spectra, derived as the average of the fitting residuals. The common mode spectra include any instrument effects that are uncorrelated to molecular scattering and absorption. This is done to reduce the fitting root-mean-square (rms) residuals and the overall uncertainties. These are then applied as reference spectra in fitting of the entire orbit. The fitting additionally contains additive (Poly baseline $_{\text {) }}$ and multiplicative closure polynomials $\left(\right.$ Poly scale $_{\text {) }}$, parameters for spectral shift and, potentially, squeeze (not normally used). The operational parameters and the cross sections used are provided in Table 1.

As part of the development of the OMBRO retrieval algorithm, a significant amount of effort was dedicated to algorithm "tuning", i.e., the optimization of elements in the retrieval process, including interfering absorbers like $\mathrm{O}_{2}-\mathrm{O}_{2}$. The spectral region of $343 \mathrm{~nm}$, where $\mathrm{O}_{2}-\mathrm{O}_{2}$ has an absorption feature larger than the $\mathrm{BrO}$ absorption, essentially is impossible to avoid in $\mathrm{BrO}$ retrievals: the fitting window would have to either terminate at shorter wavelengths or start past this feature, and both approaches yield low information content that is too unacceptable for the $\mathrm{BrO}$ retrievals to succeed. During the tuning process, we investigated the effects of, among many other things, including or excluding $\mathrm{O}_{2}-\mathrm{O}_{2}$, the use of different spectroscopic data sets (Greenblatt et al., 1990; Hermans et al., 1999, cross sections), shorter or longer wavelength windows for the retrieval and even extending the retrieval window beyond the $\mathrm{O}_{2}-\mathrm{O}_{2}$ absorption feature but excluding the approximate wavelength slice of the feature itself. The only approach that provided quantitatively satisfactory results - i.e., stability of the retrieval under a wide range of conditions, minimized correlation with clouds, low fitting uncertainties, consistency of OMI global total column $\mathrm{BrO}$ with published results, and low noise in pixel-to-pixel retrievals - was to exclude $\mathrm{O}_{2}-\mathrm{O}_{2}$ from the OMBRO V3. It is difficult to quantify $\mathrm{O}_{2}-\mathrm{O}_{2}$ atmospheric content from the absorption feature around $343 \mathrm{~nm}$ alone, and its correlation with absorption bands of $\mathrm{BrO}$ and $\mathrm{H}_{2} \mathrm{CO}$ leads to spectral correlations in the course of the nonlinear least squares minimization process that are detrimental to the $\mathrm{OMI} \mathrm{BrO}$ retrievals. Lampel et al. (2018) provide spectrally resolved $\mathrm{O}_{2-}$ $\mathrm{O}_{2}$ cross sections not only at $343 \mathrm{~nm}$ but also at $328 \mathrm{~nm}$ (see Fig. 1), which is about $20 \%$ of the absorption at $343 \mathrm{~nm}$ and has not been shown in previous $\mathrm{O}_{2}-\mathrm{O}_{2}$ cross sections. Future updates to the operational OMBRO algorithm will investigate the effect of including Lampel et al. (2018) $\mathrm{O}_{2}-\mathrm{O}_{2}$ cross sections on the fitting.

\subsection{Air mass factors}

Due to significant variation in $\mathrm{O}_{3}$ absorption and Rayleigh scattering in the fitting window AMFs vary with wavelength by $10 \%-15 \%$ as shown in Fig. 2. At large solar and viewing zenith angles it is difficult to identify a single representative AMF ad hoc. The wavelength-dependent AMFs are introduced to take into account for such strong variation within the $\mathrm{BrO}$ fitting window. They are applied prior to fitting to the BrO cross sections, and the spectral fit retrieves VCDs directly. This direct fitting approach is a major departure from the commonly employed two-step fitting procedure (OMI, 2002). It was first developed for retrievals of trace gases from SCIAMACHY radiances in the shortwave infrared (Buchwitz et al., 2000) and has been demonstrated for total $\mathrm{O}_{3}$ and $\mathrm{SO}_{2}$ retrievals from GOME/SCIAMACHY measurements in 

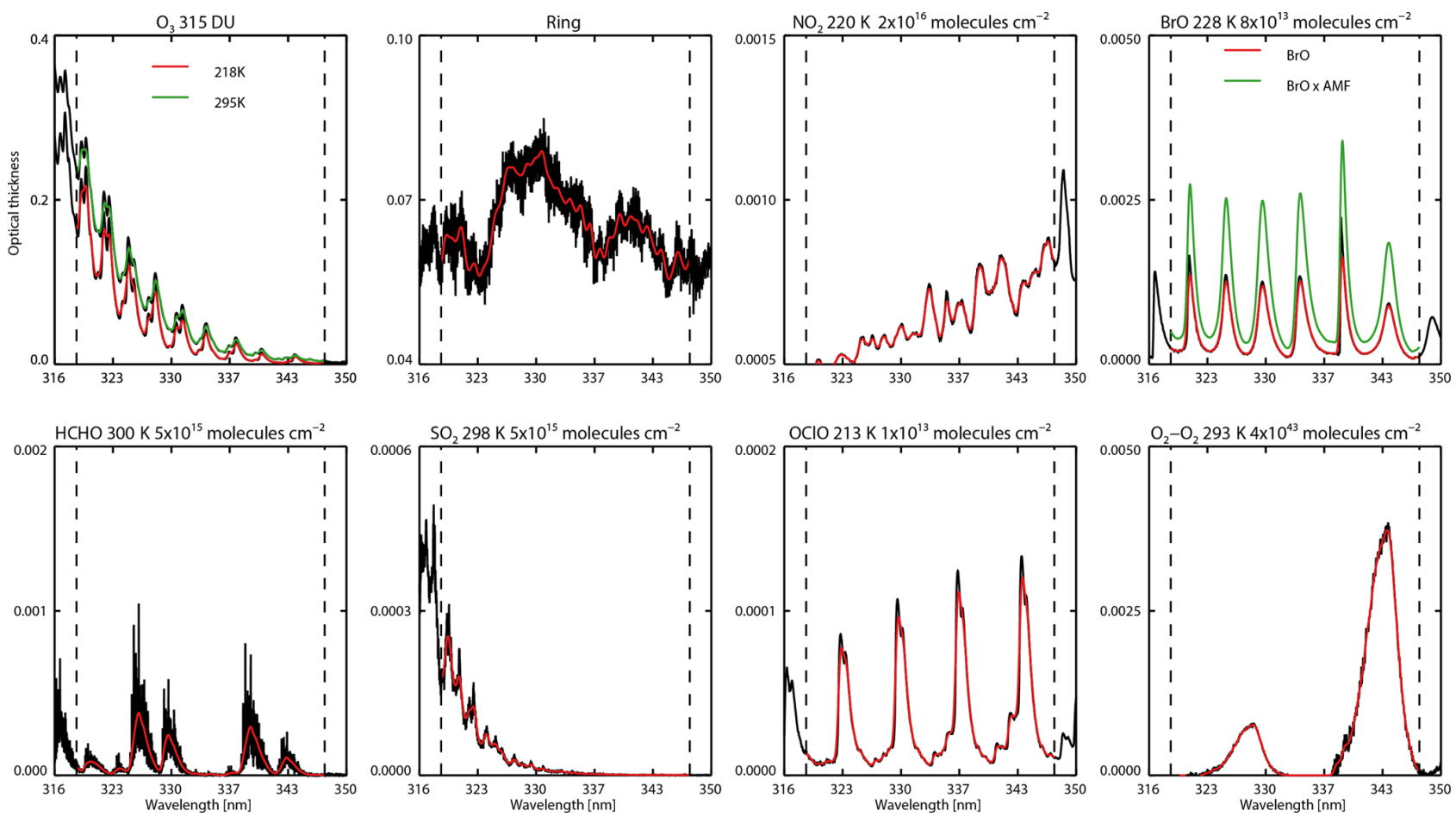

Figure 1. Cross sections used in the current operational $\mathrm{BrO}$ algorithm except for the $\mathrm{SO}_{2}$ cross section at $298 \mathrm{~K}$ which is to be used in the next version. The black lines are the original cross sections, and the colored lines show the cross sections convolved with approximate OMI slit function (which is assumed to be a Gaussian with $0.42 \mathrm{~nm}$ full width at half maximum). The $\mathrm{O}_{2}-\mathrm{O}_{2}$ calculation is based on Lampel et al. (2018) cross sections. The BrO cross section after multiplication with the wavelength-dependent AMFs used these parameters for the AMF calculation: albedo $=0.05, \mathrm{SZA}=5.0^{\circ}$ and $\mathrm{VZA}=2.5^{\circ}$. The rms of the fitting residuals is on the order of $9 \times 10^{-4}$, indicating that $\mathrm{BrO}$ spectral features are slightly bigger than typical fitting residuals.

Table 1. Fitting window and parameters used to derive $\mathrm{BrO}$ vertical column densities.

\begin{tabular}{ll}
\hline Parameter & Description/value \\
\hline Fitting window & $319.0-347.5 \mathrm{~nm}$ \\
Baseline polynomial & Fourth-order \\
Scaling polynomial & Fourth-order \\
Instrument slit function & Hyper-parameterization of preflight measurements; Dirksen et al. (2006) \\
Wavelength calibration & Spectral shift (no squeeze) \\
Solar reference spectrum & Chance and Kurucz (2010) \\
BrO cross sections & Wilmouth et al. (1999), 228 K \\
$\mathrm{H}_{2} \mathrm{CO}$ cross sections & Chance and Orphal (2011), 300 K \\
$\mathrm{O}_{3}$ cross sections & Malicet et al. (1995), 218, 295 K \\
$\mathrm{NO}_{2}$ cross sections & Vandaele et al. (1998), 220 K \\
$\mathrm{SO}_{2}$ cross sections & Vandaele et al. (1994), 295 Ka. Hermans et al. (2009); Vandaele et al. (2009), 295 K \\
$\mathrm{OClO}^{\mathrm{b}}$ cross sections & Kromminga et al. (2003), 213 K \\
Molecular Ring cross sections & Chance and Spurr (1997) \\
Undersampling correction & Computed online; Chance et al. (2005) \\
Residual (common mode) spectrum & Computed online between $30^{\circ} \mathrm{N}$ and $30^{\circ} \mathrm{S}$ \\
\hline
\end{tabular}

${ }^{\text {a }}$ Used in the current operational algorithm.

${ }^{\mathrm{b}}$ Used for testing sensitivity to $\mathrm{SO}_{2}$ cross sections and will be used in the next version. 


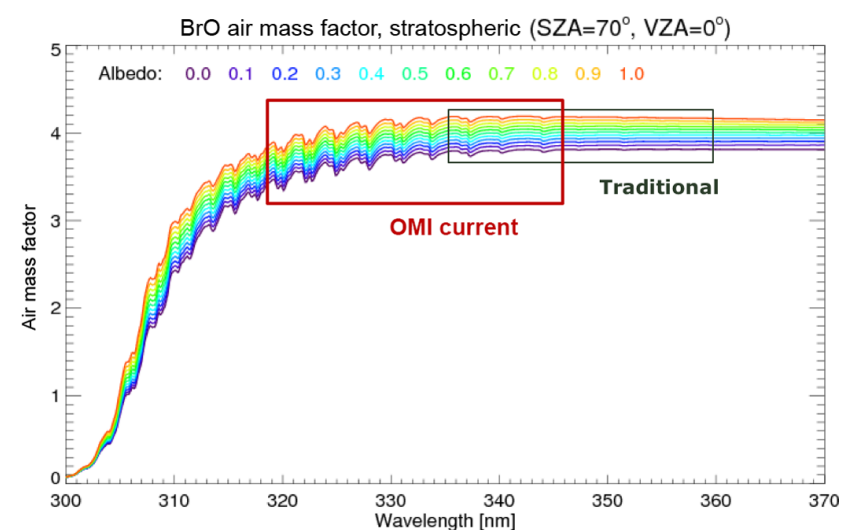

Figure 2. Wavelength- and albedo-dependent air mass factors calculated using a mostly stratospheric fixed $\mathrm{BrO}$ profile. The blue box shows the fitting window used in our previous versions, and the red box shows the fitting window used in the current operational algorithm.

the ultraviolet (Bracher et al., 2005; Coldewey-Egbers et al., 2005; Weber et al., 2005; Lee et al., 2008).

The albedo- and wavelength-dependent AMFs were precomputed with the Linearized Discrete Ordinate Radiative Transfer code (LIDORT, Spurr, 2006) using a single mostly stratospheric BrO profile (Fig. 3, left panel). The BrO profile, based on the model of Yung et al. (1980), has $\sim 30 \%$ $\mathrm{BrO}$ below $15 \mathrm{~km}, \sim 10 \%$ BrO below $10 \mathrm{~km}$ and $\sim 2 \% \mathrm{BrO}$ below $5 \mathrm{~km}$. It should be noted that a fixed profile is inconsistent with the varying tropopause height (both with latitude and dynamically, e.g., Salawitch et al., 2010) and therefore with the profile shape in the stratosphere, but the impact on the AMF is typically small as the scattering weight does not change much in the stratosphere. For conditions with enhanced $\mathrm{BrO}$ in the lower troposphere, using this profile will overestimate the AMFs and therefore underestimate the $\mathrm{BrO}$ VCDs as discussed in Sect. 3.5. Surface albedos are based on a geographically varying monthly mean climatology derived from OMI (Kleipool et al., 2008). Although AMFs based on this BrO profile only slightly depend on surface albedo, albedo effects can be significant over highly reflective snow or ice surfaces, reducing VCDs by $5 \%-10 \%$.

In order to provide the AMF in the data product for consistency with previous versions based on a two-step approach, a second fitting of all OMI spectra is performed with unmodified $\mathrm{BrO}$ cross sections, which yields SCDs. An effective $\mathrm{AMF}$ can then be computed as $\mathrm{AMF}=\mathrm{SCD} / \mathrm{VCD}$.

The green line in the top right panel of Fig. 1 shows the modified $\mathrm{BrO}$ cross section after multiplication with the wavelength-dependent AMF (albedo $=0.05$, SZA (solar zenith angle) $=5.0^{\circ}$, and VZA (viewing zenith angle $)=2.5^{\circ}$ ). The wavelength dependence in AMF is visible from the varying differences near $\mathrm{BrO}$ absorption peaks and the right wings at different wavelengths. The correlation of the unmodified $\mathrm{BrO}$ cross sections with the rest of the fit-
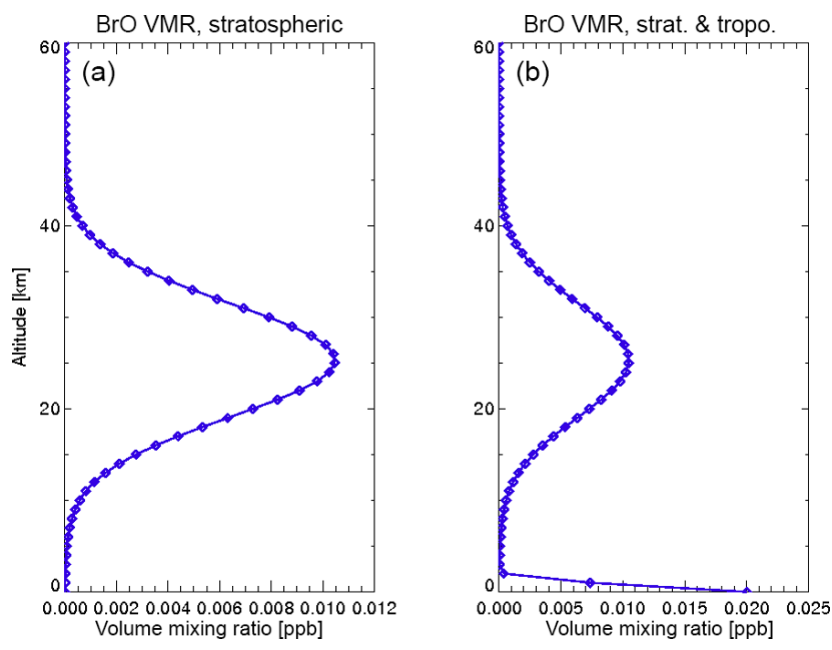

Figure 3. (a) A mostly stratospheric vertical $\mathrm{BrO}$ profile used for air mass factors calculations in OMBRO V3. Total $\mathrm{BrO}, \mathrm{BrO}$ $<15 \mathrm{~km}, \mathrm{BrO}<10 \mathrm{~km}$ and $\mathrm{BrO}<5 \mathrm{~km}$ are $2.05 \times 10^{13}, 5.06 \times$ $10^{12}, 1.55 \times 10^{12}$ and $2.87 \times 10^{11}$ molecules $\mathrm{cm}^{-2}$, respectively. (b) A stratospheric tropospheric vertical $\mathrm{BrO}$ profile used to investigate the impact of high tropospheric $\mathrm{BrO}$ columns on air mass factors calculations. Total $\mathrm{BrO}, \mathrm{BrO}<15 \mathrm{~km}, \mathrm{BrO}<10 \mathrm{~km}$ and $\mathrm{BrO}<5 \mathrm{~km}$ are $6.99 \times 10^{13}, 5.45 \times 10^{13}, 5.10 \times 10^{13}$ and $4.97 \times 10^{13}$ molecules $\mathrm{cm}^{-2}$, respectively.

ted molecules is small (typically less than 0.12 ), except with $\mathrm{H}_{2} \mathrm{CO}(0.43)$. However, it is safe to assume that in most polar regions with enhanced $\mathrm{BrO}$ there are no high concentrations of formaldehyde. It will be worthwhile for future studies to assess the interference of $\mathrm{H}_{2} \mathrm{CO}$ under high $\mathrm{H}_{2} \mathrm{CO}$ and background $\mathrm{BrO}$ conditions, similar to De Smedt et al. (2015). In addition, the AMF wavelength dependence increases with the increase of solar and viewing zenith angles and surface albedo, which increases the correlation between modified $\mathrm{BrO}$ cross sections and $\mathrm{O}_{3}$ cross sections. However, the correlation with $\mathrm{O}_{3}$ only becomes noticeable $(\sim 0.10)$ at SZAs above $\sim 80^{\circ}$.

\subsection{Destriping}

OMI L1b data exhibit small differences with cross-track position, due to differences in the dead/bad pixel masks (crosstrack positions are mapped to physically separate areas on the CCD), dark current correction and radiometric calibration, which lead to cross-track stripes in the level 2 product (Veihelmann and Kleipool, 2006). Our destriping algorithm employs several methods to reduce cross-track striping of the $\mathrm{BrO}$ columns. First, we screen outliers in the fitting residuals. This method, originally developed to mitigate the effect of the South Atlantic Anomaly in $\mathrm{SAO} \mathrm{OMI} \mathrm{BrO,} \mathrm{H}_{2} \mathrm{CO}$, and $\mathrm{OClO}$ data products, is now also being employed for GOME2 (Richter et al., 2011). Screening outliers is done through computing the median, $r_{\text {med }}$, and the standard deviation $\sigma$ of residual spectra $r(\lambda)$ and in subsequent refitting excluding 
any spectral points for which $r(\lambda) \geq\left|r_{\text {med }} \pm 3 \sigma\right|$. This can be done repeatedly for every ground pixel, which makes the processing slow. However, we do it once for a reference swath line, recording the positions of the bad pixels and excluding them by default in each subsequent fit. Second, after the completion of the spectral fitting process for all ground pixels in the granule, a post-processing cross-track bias correction is performed: an average cross-track pattern is calculated from the along-track averages of all $\mathrm{BrO}$ VCDs for each crosstrack position within a $\pm 30^{\circ}$ latitude band around the Equator, to which a low-order polynomial is fitted. The differences between the cross-track pattern and the fitted polynomial are then applied as a cross-track VCD correction (or "smoothing") factor. The smoothed VCDs are provided in a separate data field, ColumnAmountDestriped. Smoothed SCDs are derived in an analogous fashion and are also included in the data product.

\subsection{BrO VCD error analysis}

Estimated fitting uncertainties are given as $\sigma_{i}=\sqrt{\mathbf{C}_{i i}}$, where $\mathbf{C}$ is the covariance matrix of the standard errors. This definition is only strictly true when the errors are normally distributed. In the case in which the level 1 data product uncertainties are not reliable estimates of the actual uncertainties, spectral data are given unity weight over the fitting window, and the $1 \sigma$ fitting error in parameter $i$ is determined as

$\sigma_{i}=\varepsilon_{\text {rms }} \sqrt{\frac{c_{i i} \times n \text { points }}{n \text { points }-n \text { varied }}}$,

where $\varepsilon_{\text {rms }}$ is the root mean square of the fitting residuals, " $n$ points" is the number of points in the fitting window and " $n$ varied" is the number of parameters varied during the fitting.

The fitting uncertainties for single measurements of the BrO VCDs typically vary between $4 \times 10^{12}$ and $7 \times 10^{12}$ molecules $\mathrm{cm}^{-2}$, consistently throughout the data record. The uncertainties vary with cross-track positions, from $\sim 7 \times 10^{12}$ at nadir positions to $\sim 4 \times 10^{12}$ at edge positions due to the increase of photon path length through the stratosphere. Relatively, the VCD uncertainties typically range between $10 \%$ and $20 \%$ of individual BrO VCDs but could be as low as $5 \%$ over BrO hotspots. This is roughly 2-3 times worse that what was achieved from GOME-1 data.

The BrO VCD retrieval uncertainties listed in the data product only include random spectral fitting errors. Error sources from AMFs (i.e., BrO climatology), atmospheric composition and state (pressure-temperature vertical profiles, total $\mathrm{O}_{3}$ column, etc.) and other sources of VCD uncertainty are not included. We provide error estimates for these additional error sources here.

Uncertainties in the AMFs, used to convert slant to vertical columns, are estimated to be $10 \%$ or less except when there is substantially enhanced tropospheric $\mathrm{BrO}$. Hence

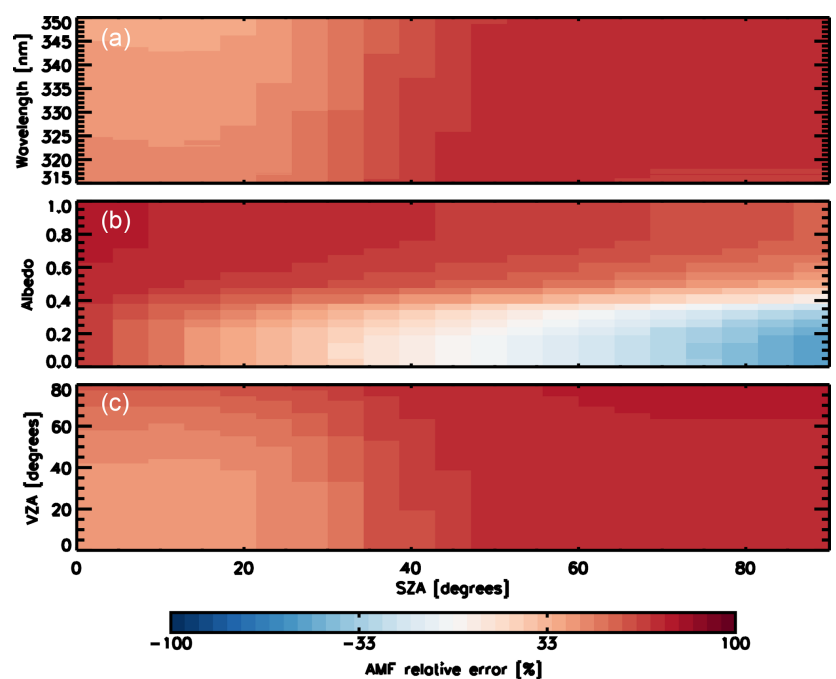

Figure 4. The percentage of relative AMF errors as a function of the SZA and the wavelength (a), albedo (b) and VZA (c) when using the stratospheric-only $\mathrm{BrO}$ profile (Fig. 3a) in the case there is a significant tropospheric $\mathrm{BrO}$ column as shown in the stratospherictropospheric $\mathrm{BrO}$ profile (Fig. 3b).

the total uncertainties of the $\mathrm{BrO}$ vertical columns typically range within $15 \%-30 \%$. To estimate the AMF error associated with enhanced tropospheric concentrations, we have studied the difference between AMFs calculated using the stratospheric-only $\mathrm{BrO}$ profile and a stratospherictropospheric profile as shown in Fig. 3b. Figure 4 shows the dependency of the relative AMF difference with respect to wavelength (panel a), albedo (panel b) and VZA (panel c) as a function of the SZA between calculations performed using these two profiles. The use of the stratospheric-only $\mathrm{BrO}$ profile can lead to AMF errors up to $50 \%$ depending on albedo and viewing geometry. On average, using the stratospheric-only $\mathrm{BrO}$ profile overestimates AMF and underestimates VCD by $41 \%$.

We have performed sensitivity analysis of OMI BrO VCD with respect to various retrieval settings using orbit 26564 on 13 July 2009. Table 2 shows the median VCDs, median fitting uncertainties and the number of negative VCD pixels for each configuration. Table 3 summarizes the overall fitting error budget including the random fitting uncertainty, cross section errors (as reported in the literature) and various retrieval settings. We studied five wavelength windows including the current operational window $(319.0-347.5 \mathrm{~nm})$ version 2 window $(323.0-353.5 \mathrm{~nm})$, version $1(340.0-357.5 \mathrm{~nm})$ and two extra windows, exploring the impact of extending the window to shorter wavelengths $(310.0-357.5 \mathrm{~nm})$ and reducing it by limiting its extension to wavelengths above $325 \mathrm{~nm}$ (325.0-357.5). The choice of fitting window can cause significant differences in $\mathrm{BrO}$ VCDs of up to $50 \%$. The current window results in the most stable retrievals with the smallest number of pixels with negative VCD values. 
Table 2. Error analysis studies. For reference, the total number of retrieved pixels not affected by the row anomaly is 58112 .

\begin{tabular}{|c|c|c|c|}
\hline Description & $\begin{array}{r}\text { Median VCD } \\
\left(\text { molecules } \mathrm{cm}^{-2} \text { ) }\right.\end{array}$ & $\begin{array}{l}\text { Median uncertainty } \\
\left(\text { molecules } \mathrm{cm}^{-2}\right)\end{array}$ & $\begin{array}{r}\text { Number of } \\
\text { negatives }\end{array}$ \\
\hline 319-347.5 nm Op. (V3) & $4.02 \times 10^{13}$ & $7.11 \times 10^{12}$ & 88 \\
\hline $323.0-353.5 \mathrm{~nm}(\mathrm{~V} 2)$ & $2.65 \times 10^{13}$ & $9.27 \times 10^{12}$ & 1604 \\
\hline $340.0-357.5 \mathrm{~nm}(\mathrm{~V} 1)$ & $2.86 \times 10^{13}$ & $1.19 \times 10^{13}$ & 3351 \\
\hline $310.0-357.5 \mathrm{~nm}$ & $1.97 \times 10^{13}$ & $6.18 \times 10^{12}$ & 2728 \\
\hline $325.0-357.5 \mathrm{~nm}$ & $3.16 \times 10^{13}$ & $8.02 \times 10^{12}$ & 1416 \\
\hline With $\mathrm{O}_{2}-\mathrm{O}_{2}$ & $3.54 \times 10^{13}$ & $7.80 \times 10^{12}$ & 319 \\
\hline Online slit function & $5.09 \times 10^{13}$ & $7.16 \times 10^{12}$ & 68 \\
\hline Without common mode & $3.89 \times 10^{13}$ & $1.02 \times 10^{13}$ & 116 \\
\hline Without $\mathrm{H}_{2} \mathrm{CO}$ & $2.52 \times 10^{13}$ & $6.27 \times 10^{12}$ & 816 \\
\hline
\end{tabular}

Table 3. Summary of different errors sources in the BrO vertical column.

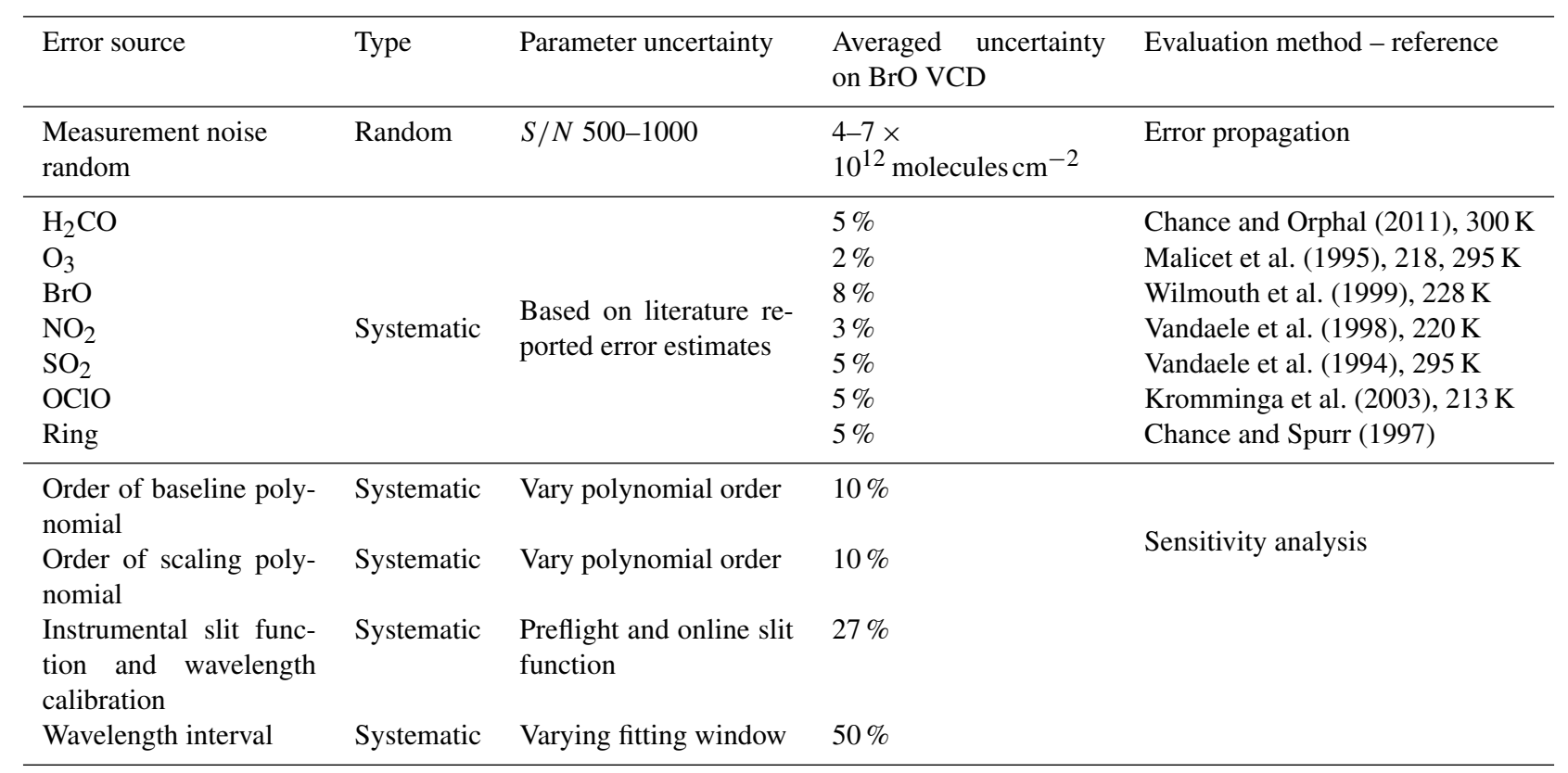

Including the interference of $\mathrm{O}_{2}-\mathrm{O}_{2}$ leads to a decrease of the median VCD by $\sim 12 \%$ and an increase of the median fitting uncertainty by $\sim 10 \%$ with respect to the operational setup. Excluding $\mathrm{H}_{2} \mathrm{CO}$ from the fitting significantly reduces the retrieved $\mathrm{BrO}$ columns by $\sim 37 \%$, given that the strong anticorrelation between both molecules is not taken into account. Fitting the mean residual (common mode) has a small impact on the retrieval results; the median VCD only changes $\sim 3 \%$ but reduces the median fitting uncertainty by $\sim 30 \%$ with respect to the exclusion of the common mode. To study the impact of the slit functions, we have performed the retrieval using both online slit functions, modeled as a Gaussian, and the preflight instrument slit functions. The median difference between these two retrievals is $27 \%$ for orbit number 26564. We have investigated the impacts of the order of scaling and baseline polynomials; it can cause uncertainties of $\sim 10 \%$ as shown in Table 3 .

To study the impact of the radiative transfer effects of the $\mathrm{O}_{3}$ absorption in our retrieval, we have adopted the correction method described by Puksite et al. (2010). We find that between $60^{\circ} \mathrm{S}$ and $60^{\circ} \mathrm{N}$, the average difference is smaller than $10 \%$, with values around $2 \%$ near the Equator. However, as we move near the poles with solar zenith angles above $60^{\circ}$, the differences start to be bigger, arriving at mean values around $30 \%$.

\section{Results and discussions}

Comparisons of the OMI OMBRO product with GOME-2 satellite retrievals and remote sensing ground-based measurements over Harestua, Norway, as well as monthly mean 
averages illustrate the quality of the retrieval on a global scale. On a local scale, recent scientific studies looking at $\mathrm{BrO}$ enhancements in volcanic plumes and over salt lakes are pushing the limits of the current OMBRO setups. In the following sections, we provide details of these comparisons (Sect. 4.1) and discuss OMI OMBRO global distribution (Sect. 4.2) and local enhancements over salt lakes and volcanic plumes observations (Sect. 4.3) and their applicability and strategies to correctly use the publicly available OMBRO product.

\subsection{Comparisons with GOME-2 and ground-based observations}

To assess the quality of the OMBRO product, we first compared OMI BrO VCDs with BIRA/GOME-2 BrO observations (Theys et al., 2011). GOME-2 has a descending orbit with a local Equator crossing time (ECT) of 09:30, and OMI has an ascending orbit with an ECT of 13:45. To minimize the effects of diurnal variation, especially under high SZAs (e.g., McLinden et al., 2006; Sioris et al., 2006), on the comparison, we conduct the comparison using simultaneous nadir overpasses (SNOs) within 2 min between GOME-2 and OMI predicted by NOAA National Calibration Center's SNO prediction tool (https://ncc.nesdis.noaa. gov/SNOPredictions, last access: 15 October 2017). Given Aura and Metop-A satellite orbits, all these SNOs occur at high latitudes around $75^{\circ} \mathrm{S}$ and $75^{\circ} \mathrm{N}$. Figure 5 shows the time series of comparison of individual OMI/GOME-2 BrO retrievals from February 2007 through November 2008. The temporal variation of $\mathrm{BrO}$ at the $\mathrm{SNO}$ locations is captured similarly by OMI and GOME-2 BrO. The scatter plot in Fig. 6 quantifies the comparison between OMI and GOME-2 BrO. OMI BrO shows excellent agreement with GOME-2 BrO, with a correlation of 0.74 and a mean bias of $-0.216 \pm 1.13 \times 10^{13}$ molecules $\mathrm{cm}^{-2}$ (mean relative bias of $-2.6 \pm 22.1 \%$ ). Considering very different retrieval algorithms including different cross sections and $\mathrm{BrO}$ profiles, such a good agreement is remarkable. GOME-2 retrievals use the $\mathrm{BrO}$ cross sections of Fleischmann et al. (2004), while our $\mathrm{BrO}$ retrievals use the $\mathrm{BrO}$ cross sections of Wilmouth et al. (1999). According to the sensitivity studies by Hendrick et al. (2009), using the Fleischmann cross section increases $\mathrm{BrO}$ by $\sim 10 \%$. So, accounting for different cross sections, OMI BrO underestimates the GOME- $2 \mathrm{BrO}$ by $\sim 10 \%$. In addition, the GOME- 2 algorithm uses a residual technique to estimate tropospheric $\mathrm{BrO}$ from measured $\mathrm{BrO}$ SCDs by subtracting a dynamic estimate of stratospheric $\mathrm{BrO}$ climatology driven by $\mathrm{O}_{3}$ and $\mathrm{NO}_{2}$ concentrations and by using two different tropospheric $\mathrm{BrO}$ profiles depending on surface albedo conditions. This is very different from the approach of using a single $\mathrm{BrO}$ profile in the OMI BrO algorithm and can contribute to some of the $\mathrm{BrO}$ differences. Furthermore, additional algorithm uncertainties in both algorithms and different spatial sampling can also cause some

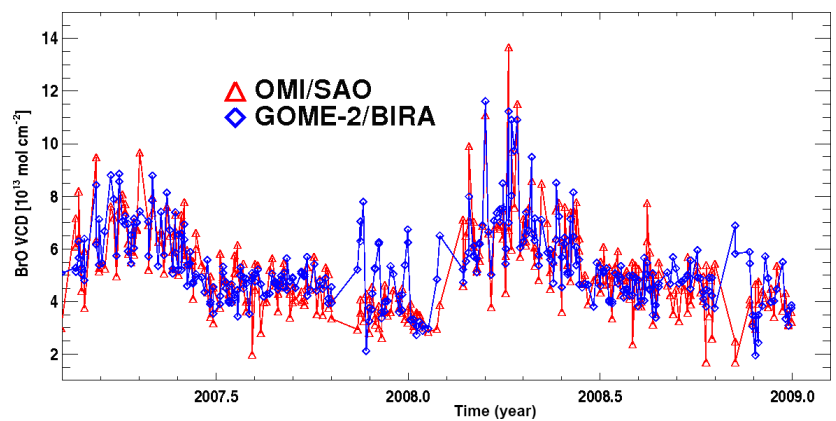

Figure 5. Time series comparison of SAO OMI (red) $\mathrm{BrO}$ and BIRA/GOME-2 (blue) BrO VCDs from February 2007 to November 2008 using simultaneous nadir overpasses occurring at high latitudes, around $75^{\circ} \mathrm{S}$ and $75^{\circ} \mathrm{N}$, and within 2 min between OMI and GOME-2 observations.

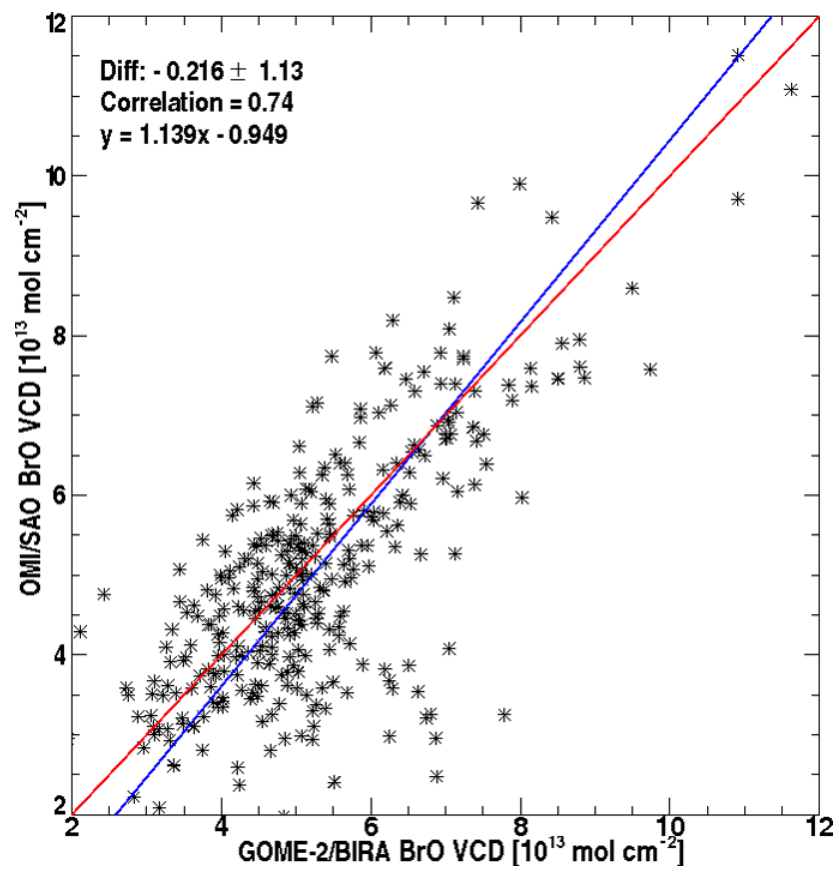

Figure 6. Correlation and orthogonal regression of OMI and GOME-2 BrO for the data shown in Fig. 5. The legends show the mean bias and standard deviation of the differences, correlation and the orthogonal regression.

differences. Figure 7 shows the VCD monthly averages of GOME-2 data (green) and OMBRO (black) from February 2007 to December 2009, for which the seasonal variations are clearly seen. Our study shows that OMI has negative mean biases of $0.35 \times 10^{13}$ molecules $\mathrm{cm}^{-2}(12 \%), 0.33 \times$ $10^{13}$ molecules $\mathrm{cm}^{-2}(10 \%), \quad 0.25 \times 10^{13}$ molecules $\mathrm{cm}^{-2}$ $(17 \%)$ and $0.30 \times 10^{13}$ molecules $\mathrm{cm}^{-2}(10 \%)$ for Alaska, the South Pacific, Hudson Bay and Greenland, respectively.

We also used ground-based zenith-sky measurements of total column $\mathrm{BrO}$ at Harestua, Norway (Hendrick et al., 2007) to estimate the quality of the OMI BrO. We com- 

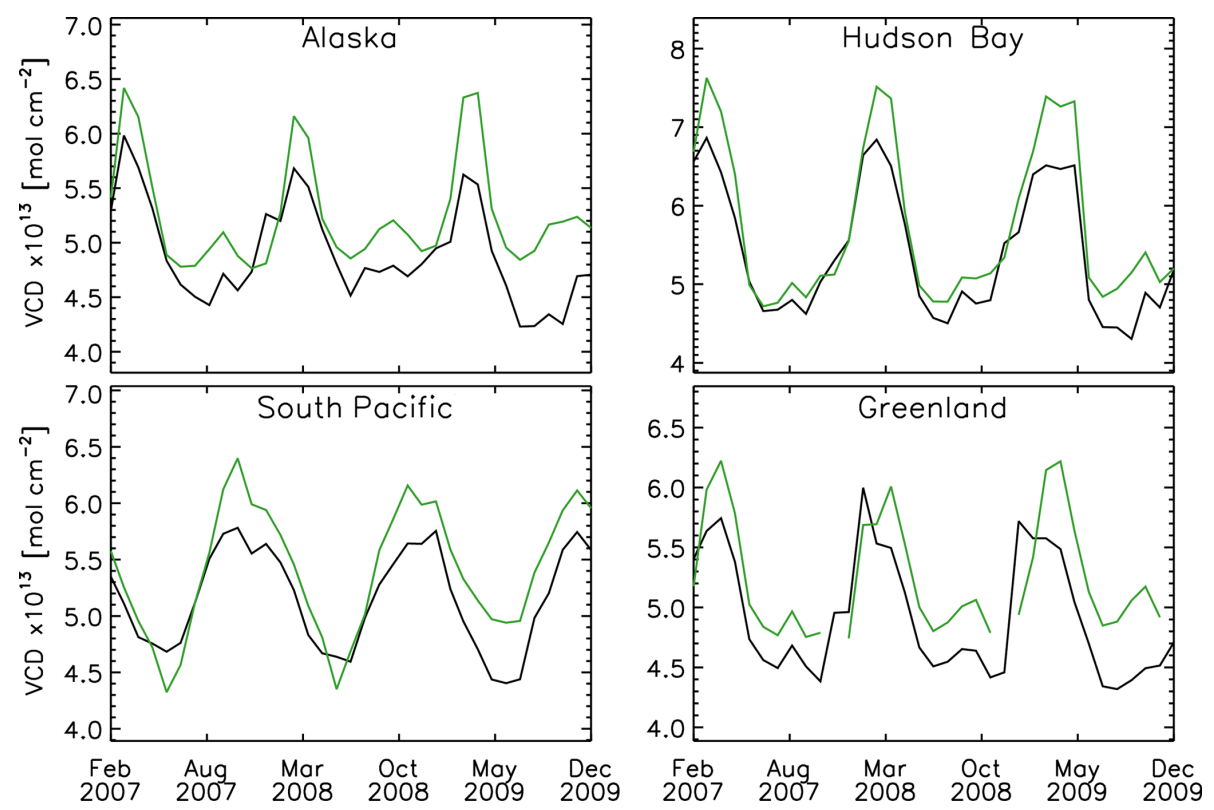

Figure 7. VCD of GOME-2 (green) comparison to OMI (black) over four regions from February 2007 to December 2009 for four regions. Each region is defined by a square with the following latitude and longitude boundaries: Alaska (50-70 $\left.\mathrm{N}, 165-135^{\circ} \mathrm{W}\right), \mathrm{Hudson}$ Bay $\left(50-65^{\circ} \mathrm{N}, 95-75^{\circ} \mathrm{W}\right)$, the South Pacific $\left(70-50^{\circ} \mathrm{S}, 135-155^{\circ} \mathrm{E}\right)$ and Greenland $\left(60-80^{\circ} \mathrm{N}, 60-15^{\circ} \mathrm{W}\right)$.

pared daily mean total $\mathrm{BrO}$ at Harestua with the mean OMI $\mathrm{BrO}$ from individual footprints that contain the location of Harestua site. Figure 8 shows the time series of the comparison between $\mathrm{OMI}$ total $\mathrm{BrO}$ and Harestua total $\mathrm{BrO}$ from February 2005 through August 2011 with the scatter plot shown in Fig. 9. Ground-based BrO shows an obvious seasonality with high values in the winter-spring and low values in the summer-fall. Such seasonality is well captured by OMI BrO. OMI BrO shows a reasonable good agreement with Harestua $\mathrm{BrO}$, with a correlation of 0.46 and a mean bias of $0.12 \pm 0.76 \times 10^{13}$ molecules $\mathrm{cm}^{-2}$ (mean relative bias of $3.18 \pm 16.30 \%$, with respect to individual Harestua $\mathrm{BrO}$ ). Sihler et al. (2012) compared GOME-2 BrO to ground-based observations at Utqiagivik (formerly Barrow), finding the correlation to be weaker $(r=0.3)$, likely due to both elevated and shallow surface layers of $\mathrm{BrO}$. However, their correlation between GOME-2 $\mathrm{BrO}$ and ground-based measurements made from the icebreaker Amundsen, in the Canadian Arctic Ocean $(r=0.4)$, is closer to our correlation here. From the Harestua data, tropospheric $\mathrm{BrO}$ typically consists of $15 \%$ $30 \%$ of the total $\mathrm{BrO}$, larger than what we have assumed in the troposphere. The use of a single $\mathrm{BrO}$ profile in the OMI $\mathrm{BrO}$ algorithm will likely underestimate the actual $\mathrm{BrO}$. Accounting for the uncertainty due to profile shape, $\mathrm{OMI} \mathrm{BrO}$ will have a larger positive bias relative to Harestua measurements, which can be caused by other algorithm uncertainties and the spatiotemporal differences between OMI and Harestua BrO.

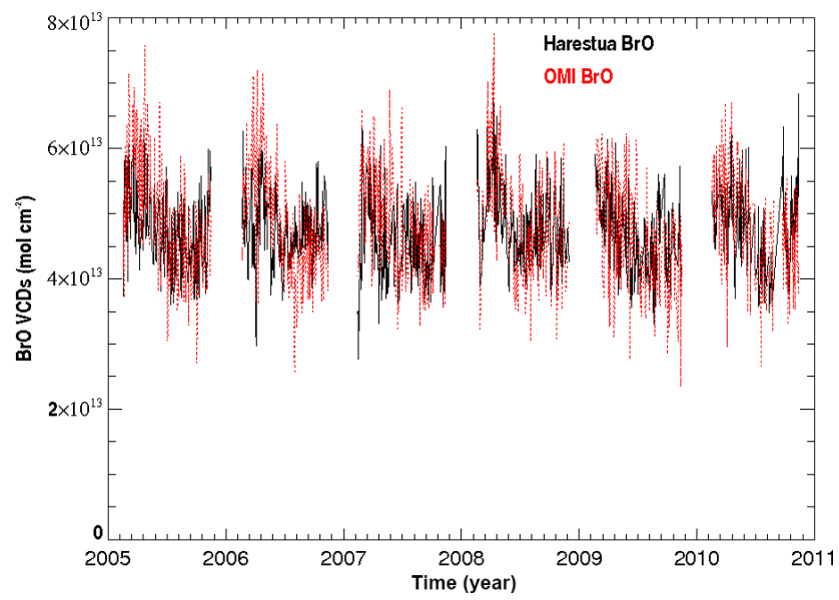

Figure 8. Time series comparison of ground-based zenith-sky total $\mathrm{BrO}$ (black) at Harestua, Norway, and coincident SAO OMI BrO (red) from February 2005 through August 2011.

\subsection{Global distribution of BrO VCDs}

Figure 10 presents the global distribution of monthly mean BrO VCDs for selected months (March, June, September, December), showing $\mathrm{BrO}$ seasonality for three different years (2006, 2007 and 2012). BrO typically increases with latitude, with minimal values in the tropics $\left(\sim 2 \times 10^{13}\right.$ molecules $\left.\mathrm{cm}^{-2}\right)$ and maximum values $\left(\sim 10^{14}\right.$ molecules $\left.\mathrm{cm}^{-2}\right)$ around polar regions especially in the Northern Hemisphere winter-spring. In the tropics, $\mathrm{BrO}$ shows little seasonality, but at higher latitudes in polar re- 


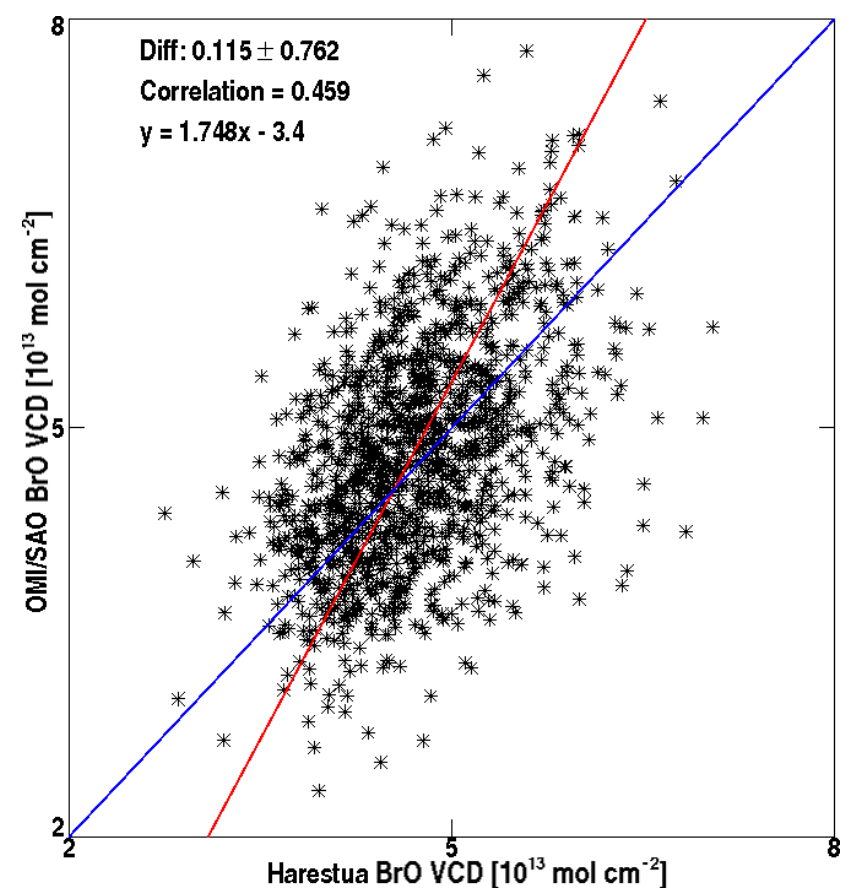

Figure 9. Correlation and orthogonal regression of OMI and Harestua BrO for the data in Fig. 8. The legends show the mean biases and standard deviations of the differences, correlation and the orthogonal regression.

gions, $\mathrm{BrO}$ displays evident seasonality. The seasonality is different between the Northern and Southern Hemisphere. In the Northern Hemisphere, $\mathrm{BrO}$ values are larger in spring (March) with widespread enhancement and are smaller in fall (September/December). In the Southern Hemisphere, BrO values are larger in southern hemispheric spring and summer (i.e., September and December) and smaller in the winter (June). Such global distribution and seasonal variation are generally consistent with previous satellite measurements (cf. Chance, 1998; http://bro.aeronomie.be/level3_monthly. php?cmd=map, last access: 15 October 2017). BrO in the tropics shows consistent zonal distributions, with lower values over land and in the intertropical convergence zone. This might be related to the impacts of clouds on the retrievals (e.g., BrO below thick clouds cannot be measured; there are uncertainties in the AMF calculation under cloudy conditions) and will be investigated in detail in future studies. The global distribution and seasonal variation are consistent from year to year, but the distributions from different years disclose some interannual variation. For example, $\mathrm{BrO}$ values in 2007 are smaller in January but are larger in March compared to those in 2006. Although OMI data since 2009 have been seriously affected by the row anomaly at certain crosstrack positions, the monthly mean data derived from good cross-track positions are hardly affected by the row anomaly as shown by the very similar global distribution and seasonality in 2012 .

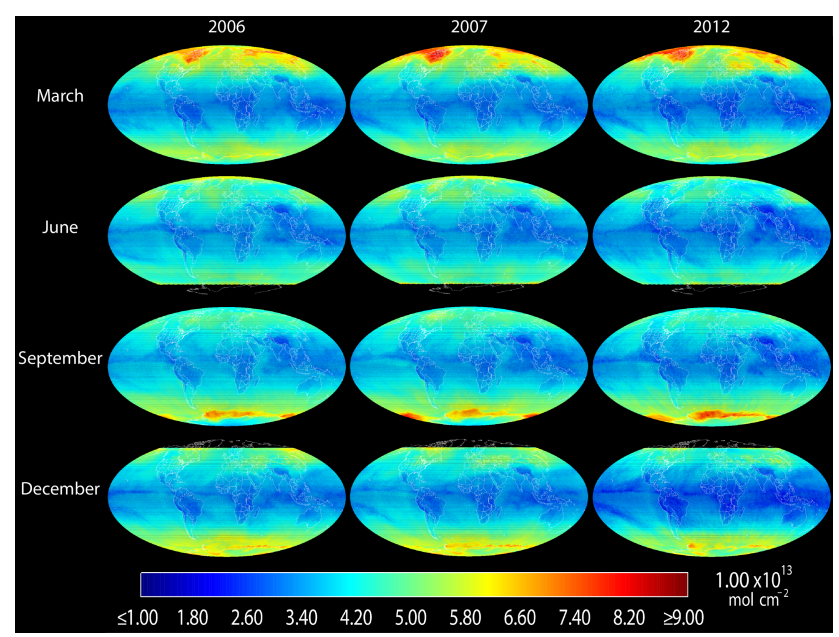

Figure 10. Global distributions of monthly mean BrO VCDs in March, June, September and December (in different rows) of 2006, 2007 and 2012 (different columns). Bromine release "explosions" during the polar spring months can be seen clearly.

\subsection{Salt lakes and volcanic plumes enhancements of BrO}

Following recent work by Hörmann et al. (2016) over the Rann of Kutch using OMI BrO retrievals from an independent research product, we have explored the capability of our OMBRO product to observe similar enhancements in other salt lakes. Figure 11 shows monthly averaged OMI BrO over the Great Salt Lake for June 2006, the corresponding surface albedo used in the retrieval, cloud cover (assuming a cloud filter of $40 \%$ ), and the cloud pressure. Over the Great Salt Lake, $\mathrm{BrO}$ enhancement occurs predominantly over the lake bed, with enhancements of $\sim 5-10 \times 10^{12}$ molecules $\mathrm{cm}^{-2}$ over background values $\left(3-4 \times 10^{13}\right.$ molecules $\left.\mathrm{cm}^{-2}\right)$. Despite observing these enhancements, the users of OMBRO for these kinds of studies should be aware of three limitations of the current retrieval algorithm. First, the $\mathrm{BrO}$ columns assume a mostly stratospheric $\mathrm{BrO}$ profile (Fig. 3a) for the AMF calculation. Second, the OMI-derived albedo climatology (Kleipool et al., 2008) used in OMBRO has a resolution of $0.5^{\circ}$. At this resolution OMBRO retrievals can have biases given the size of OMI pixels and the inherent subpixel albedo variability. Finally, high albedos inherent to salt lakes surface yield abnormally high cloud fractions and low cloud pressures over the salt lakes (Hörmann et al., 2016). All these factors should be considered in studies addressing the spatiotemporal distribution of $\mathrm{BrO}$ over salt lakes using OMBRO.

During our analysis of volcanic eruption scenarios, it was discovered that the currently implemented $\mathrm{SO}_{2}$ molecular absorption cross sections (Vandaele et al., 1994) are a suboptimum choice (see Fig. 12). Compared to more recent laboratory measurements (Hermans et al., 2009; Vandaele et al., 

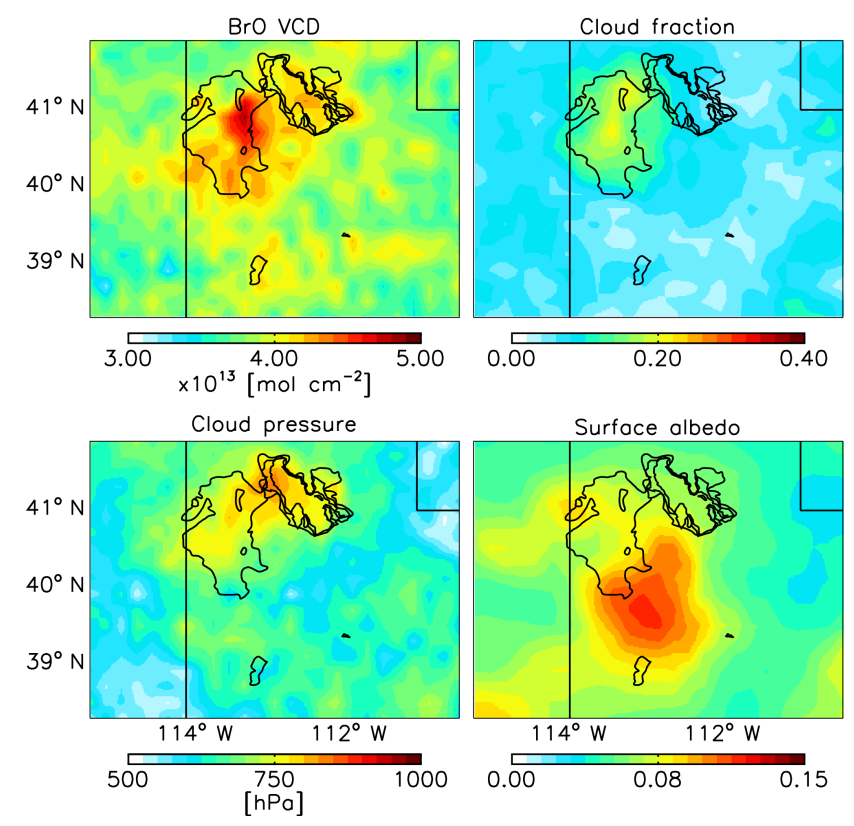

Figure 11. Mean June $2006 \mathrm{BrO}$ VCD over the Great Salt Lake area. Averages have been calculated on a $0.2^{\circ} \times 0.2^{\circ}$ grid including only pixels with cloud fractions smaller than 0.4 . The straight lines are borders of the state of Utah, and the curving lines represent the Great Salt Lake (eastern oval area) and Salt Flats (western oval area).

2009), the original $\mathrm{SO}_{2}$ cross sections implemented in OM$\mathrm{BRO}$ do not extend over the full $\mathrm{BrO}$ fitting window and exhibit the wrong behavior longward of $324 \mathrm{~nm}$, overestimating the most recent measurement by up to a factor of 3 . As the correlation between $\mathrm{BrO}$ and both $\mathrm{SO}_{2}$ cross sections is very small ( -0.03 for the current $\mathrm{SO}_{2}$ and 0.11 for the latest $\mathrm{SO}_{2}$ cross sections) over the spectral range of $\mathrm{SO}_{2}$ cross sections, interference by $\mathrm{SO}_{2}$ in $\mathrm{BrO}$ retrievals is usually not an issue at average atmospheric $\mathrm{SO}_{2}$ concentrations, but strong volcanic eruptions will render even small $\mathrm{SO}_{2}$ absorption features past $333 \mathrm{~nm}$ significant. Around $334 \mathrm{~nm}$, the Vandaele et al. (2009) data show an $\mathrm{SO}_{2}$ feature that correlates with $\mathrm{BrO}$ absorption when $\mathrm{SO}_{2}$ concentrations are significantly enhanced. As a consequence of this spectral correlation, $\mathrm{SO}_{2}$ may be partially aliased as $\mathrm{BrO}$, since the implemented $\mathrm{SO}_{2}$ cross sections cannot account for it. Figure 13 presents an example from the 2010 Eyjafjallajökull eruption to show that the $\mathrm{BrO}$ retrieval can be affected by the choice of $\mathrm{SO}_{2}$ cross sections. The next version of the OMBRO public release will be produced using the updated $\mathrm{SO}_{2}$ absorption cross sections. Until then, caution is advised when using the $\mathrm{OMI} \mathrm{BrO}$ product during elevated $\mathrm{SO}_{2}$ conditions. We recommend using the OMBRO product together with the operational OMI $\mathrm{SO}_{2}$ product (Li et al., 2013) to flag abnormally high $\mathrm{BrO}$ retrievals.

Figure $13 \mathrm{a}$ and $\mathrm{b}$ show daily average operational $\mathrm{BrO}$ VCDs from the eruption of the Eyjafjallajökull volcano on

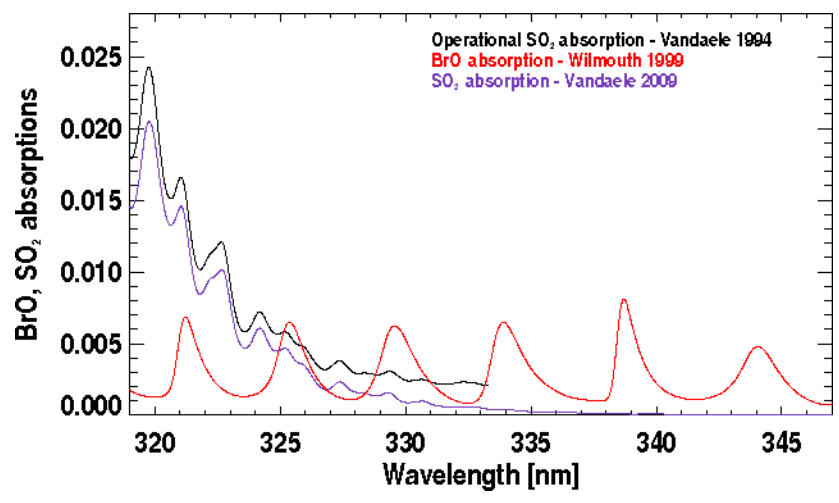

Figure 12. Comparison of $\mathrm{BrO}$ absorption (red) and $\mathrm{SO}_{2}$ absorptions under volcanic scenarios based on cross sections used in the operational algorithm (Vandaele et al., 1994) as shown in black and the recent laboratory cross sections (Vandaele et al., 2009) as shown in purple. For BrO, a SCD of $1.0 \times 10^{14}$ molecules $\mathrm{cm}^{-2}$ is assumed; for $\mathrm{SO}_{2}$, a $\mathrm{SCD}$ of 15 Dobson units (i.e., $4.03 \times$ $10^{17}$ molecules $\mathrm{cm}^{-2}$ ) is assumed. Cross sections have been convolved with the OMI slit function (which is assumed to be a Gaussian with $0.42 \mathrm{~nm}$ full width at half maximum).

5 and 17 May 2010, respectively. Enhanced $\mathrm{BrO}$ values in excess of $8.0 \times 10^{13}$ molecules $\mathrm{cm}^{-2}$ are detected in the vicinity of this volcano (e.g., plume extending southeastward from the volcano on 5 May and high BrO over Iceland on 17 May). Some of these enhanced $\mathrm{BrO}$ values correspond to the locations of enhanced $\mathrm{SO}_{2}$ as shown on the NASA global $\mathrm{SO}_{2}$ monitoring website (https://so2.gsfc.nasa.gov/, last access: 7 October 2017). This enhancement of BrO is not related to the seasonal variation of $\mathrm{BrO}$ as no such $\mathrm{BrO}$ enhancement is detected over Eyjafjallajökull during 5-17 May 2011 (a year after the eruption), with $\mathrm{BrO}$ values of only up to $\sim 5.3 \times 10^{13}$ molecules $\mathrm{cm}^{-2}$ (not shown). Figure $13 \mathrm{c}$ and $\mathrm{d}$ show the same $\mathrm{BrO}$ retrievals using $\mathrm{SO}_{2}$ cross sections by Vandaele et al. (2009). Using the improved $\mathrm{SO}_{2}$ cross sections increases the $\mathrm{BrO}$ over a broader area on both days, supporting the theory that the choice of $\mathrm{SO}_{2}$ cross sections can affect the $\mathrm{BrO}$ retrievals. However, $\mathrm{BrO}$ enhancement around the volcano can still clearly be seen with the improved $\mathrm{SO}_{2}$ cross sections. This suggests that this $\mathrm{BrO}$ enhancement is not totally due to aliasing of $\mathrm{SO}_{2}$ as $\mathrm{BrO}$ but potentially real $\mathrm{BrO}$ from the volcanic eruption.

\section{Conclusions}

This paper describes the current operational OMI BrO retrieval algorithm developed at SAO and the corresponding V3 OMI total BrO (OMBRO) product in detail. The OMI $\mathrm{BrO}$ retrieval algorithm is based on nonlinear least squares direct fitting of radiance spectra in the spectral range 319.0$347.5 \mathrm{~nm}$ to obtain vertical column densities (VCDs) directly in one step. Compared to previous versions of two-step al- 


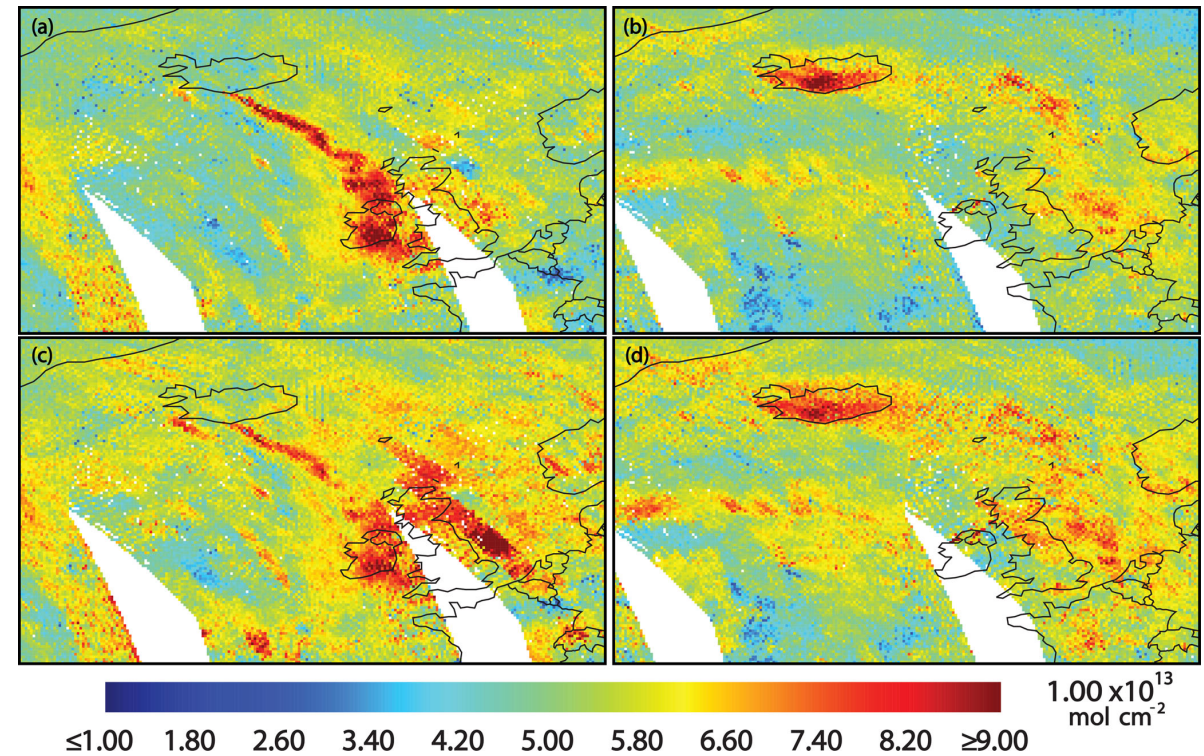

Figure 13. Daily average BrO VCDs from Eyjafjallajökull on 5 May 2010 (a) and 17 May 2010 (b) produced using the operational $\mathrm{SO}_{2}$ cross sections for the same days (c) and using the Vandaele et al. (2009) $\mathrm{SO}_{2}$ cross sections (d).

gorithms, the fitting window was moved to shorter wavelengths, and the spectral range was increased to reduce the fitting uncertainty. Because air mass factors (AMFs) vary significantly with wavelength as a result of significant variation of $\mathrm{O}_{3}$ absorption, the wavelength- and surface-albedodependent AMF, which is precomputed with the Linearized Discrete Ordinate Radiative Transfer (LIDORT) code using a single mostly stratospheric $\mathrm{BrO}$ profile, is applied prior to fitting to $\mathrm{BrO}$ cross sections for direct fitting of VCDs. Prior to the spectral fitting of $\mathrm{BrO}$, wavelength calibration is performed for both irradiance and radiance at each cross-track position, and reference spectra are properly prepared at the radiance wavelength grid. Then radiances are modeled from the measured solar irradiance, accounting for rotational Raman scattering, undersampling and attenuation from $\mathrm{BrO}$ and interfering gases and including additive and multiplicative closure polynomials and the average fitting residual spectrum. To maintain consistency with previous versions, a second fitting of all OMI spectra is performed with unmodified BrO cross sections to derive SCDs and the effective AMFs. Then a destriping step is employed to reduce the cross-trackdependent stripes.

The uncertainties of BrO VCDs included in the data product include only spectral fitting uncertainties, which typically vary between 4 and $7 \times 10^{12}$ molecules $\mathrm{cm}^{-2}(10 \%-20 \%$ of BrO VCDs; this could be as low as $5 \%$ over BrO hotspots), consistent throughout the data record. The uncertainties vary with cross-track positions, from $\sim 7 \times 10^{12}$ at nadir positions to $\sim 4 \times 10^{12}$ at edge positions. We have investigated additional fitting uncertainties caused by interferences from $\mathrm{O}_{2}-\mathrm{O}_{2}, \mathrm{H}_{2} \mathrm{CO}, \mathrm{O}_{3}$, and $\mathrm{SO}_{2}$, the impact of the choice of fitting window, the use of common mode, the orders of clo- sure polynomials and instrument slit functions. Uncertainties in the AMF calculations are estimated at $\sim 10 \%$ unless the observation is made over a region with high tropospheric $\mathrm{BrO}$ columns. In this case, the use of a single stratospheric $\mathrm{BrO}$ profile is another source of uncertainty, overestimating AMFs (up to $50 \%$ ) and therefore underestimating $\mathrm{BrO}$ VCDs.

We compared OMI BrO VCDs with BIRA/GOME-2 $\mathrm{BrO}$ observations at locations of simultaneous nadir overpasses (SNOs), which only occur around $75^{\circ} \mathrm{N}$ and $75^{\circ} \mathrm{S}$. OMI $\mathrm{BrO}$ shows excellent agreement with GOME-2 $\mathrm{BrO}$, with a correlation of 0.74 and a mean bias of $-0.216 \pm$ $1.13 \times 10^{13}$ molecules $\mathrm{cm}^{-2}$ (mean relative bias of $-2.6 \pm$ $22.1 \%$ ). Monthly mean OMBRO VCDs during 2007-2009 show negative biases of $0.25-0.35 \times 10^{13}$ molecules $\mathrm{cm}^{-2}$ (10\%-17\%) over Alaska, the South Pacific, Hudson Bay and Greenland, respectively. We also compared OMI BrO with ground-based zenith-sky measurements of total $\mathrm{BrO}$ at Harestua, Norway. The BrO seasonality in Harestua is well captured by the OMI BrO and OMBRO retrieval, showing a reasonable good agreement with the ground-based measurements. The correlation between both datasets is 0.46 , and the mean bias is $0.12 \pm 0.76 \times 10^{13}$ molecules $\mathrm{cm}^{-2}$ (mean relative bias of $3.18 \pm 16.30 \%$ ).

The global distribution and seasonal variation of OMBRO are generally consistent with previous satellite measurements. There are small values in the tropics with little seasonality and large values at high latitudes with distinct seasonality. The seasonality is different between the Northern and Southern Hemisphere, with larger values in the hemispheric winter-spring (spring-summer) and smaller values in summer-fall (winter) for the Northern (Southern) Hemi- 
sphere. This spatiotemporal variation is generally consistent from year to year and is hardly affected by the row anomaly but does show some interannual variation. Finally, we have explored the feasibility of detecting enhanced BrO column over salt lakes and in volcanic plumes using OMBRO retrievals. We found enhancement of the $\mathrm{BrO}$ with respect to the background levels of $5-10 \times 10^{12}$ molecules $\mathrm{cm}^{-2}$ over the US Great Salt Lake. We also observed a significant enhancement from the eruption of Eyjafjallajökull volcano although $\mathrm{BrO}$ retrievals under high $\mathrm{SO}_{2}$ conditions can be affected by the current use of a sub-optimal choice of $\mathrm{SO}_{2}$ cross sections.

Several important retrieval issues in the current operational algorithm that affect the quantitative use $\mathrm{BrO}$ VCDs have been raised in this paper such as the exclusion of $\mathrm{O}_{2}$ $\mathrm{O}_{2}$, nonoptimal $\mathrm{SO}_{2}$ cross sections, the neglect of the radiative effect of $\mathrm{O}_{3}$ absorption and the assumption of the stratospheric-only $\mathrm{BrO}$ profile. Users are advised to pay attention to these issues so that the product can be used properly. Future versions of OMBRO will include updated $\mathrm{SO}_{2}$ and $\mathrm{O}_{2}-\mathrm{O}_{2}$ cross sections, corrections for the radiative transfer effect of the $\mathrm{O}_{3}$ absorption, and reoptimization of the spectral fitting windows to mitigate the interferences of other trace gases. We will also improve the AMF calculation accounting for clouds and $\mathrm{O}_{3}$ and will consider the use of model-based climatological $\mathrm{BrO}$ profiles. These updates will increase the capabilities of the OMBRO retrieval to quantitatively estimate enhancements over salt lakes and in volcanic plumes.

Data availability. SAO OMI $\mathrm{BrO}$ retrievals were performed using radiance data publicly accessible at https://doi.org/10.5067/Aura/OMI/DATA1002 (Dobber, 2007). SAO OMBRO data are publicly available at https://doi.org/10.5067/Aura/OMI/DATA2006 (Chance, 2007).

Competing interests. The authors declare that they have no conflict of interest.

Acknowledgements. This study is supported by the NASA Atmospheric Composition Program/Aura Science Team (NNX11AE58G) and the Smithsonian Institution. Part of the research was carried out at the Jet Propulsion Laboratory, California Institute of Technology, under a contract with NASA. The Dutch-Finnish OMI instrument is part of the NASA EOS Aura satellite payload. The OMI project is managed by NIVR and KNMI in the Netherlands. We acknowledge the OMI International Science Team for providing the SAO OMBRO data product used in this study.

Review statement. This paper was edited by William R. Simpson and reviewed by Johannes Lampel and three anonymous referees.

\section{References}

Abbatt, J. P. D., Thomas, J. L., Abrahamsson, K., Boxe, C., Granfors, A., Jones, A. E., King, M. D., Saiz-Lopez, A., Shepson, P. B., Sodeau, J., Toohey, D. W., Toubin, C., von Glasow, R., Wren, S. N., and Yang, X.: Halogen activation via interactions with environmental ice and snow in the polar lower troposphere and other regions, Atmos. Chem. Phys., 12, 6237-6271, https://doi.org/10.5194/acp-12-6237-2012, 2012.

Acarreta, J. R., De Haan, J. F., and Stammes, P.: Cloud pressure retrieval using the $\mathrm{O}_{2}-\mathrm{O}_{2}$ absorption band at $477 \mathrm{~nm}, \quad$ J. Geophys. Res.-Atmos., 109, D05204, https://doi.org/10.1029/2003JD003915, 2004.

Aliwell, S. R., Van Roozendael, M., Johnston, P. V., Richter, A., Wagner, T., Arlander, D. W., Burrows, J. P., Fish, D. J., Jones, R. L., Tornkvist, K. K., Lambert, J.-C., Pfeilsticker, K., and Pundt, I.: Analysis for $\mathrm{BrO}$ in zenith-sky spectra: An intercomparison exercise for analysis improvement, J. Geophys. Res., 107, 4199, https://doi.org/10.1029/2001JD000329, 2002.

Begoin, M., Richter, A., Weber, M., Kaleschke, L., Tian-Kunze, X., Stohl, A., Theys, N., and Burrows, J. P.: Satellite observations of long range transport of a large BrO plume in the Arctic, Atmos. Chem. Phys., 10, 6515-6526, https://doi.org/10.5194/acp10-6515-2010, 2010.

Blechschmidt, A.-M., Richter, A., Burrows, J. P., Kaleschke, L., Strong, K., Theys, N., Weber, M., Zhao, X., and Zien, A.: An exemplary case of a bromine explosion event linked to cyclone development in the Arctic, Atmos. Chem. Phys., 16, 1773-1788, https://doi.org/10.5194/acp-16-1773-2016, 2016.

Bobrowski, N., Hönninger, G., Galle, B. and Platt, U.: Detection of bromine monoxide in a volcanic plume, Nature, 423, 273-276, 2003.

Bobrowski, N., von Glasow, R., Aiuppa, A., Inguaggiato, S., Louban, I., Ibrahim, O. W., and Platt, U.: Reactive halogen chemistry in volcanic plumes, J. Geophys. Res. Atmos., 112, D06311, https://doi.org/10.1029/2006JD007206, 2007.

Bobrowski, N., von Glasow, R., Giuffrida, G. B., Tedesco, D., Aiuppa, A., Yalire, M., Arellano, S., Johansson, M., and Galle, B.: Gas emission strength and evolution of the molar ratio of $\mathrm{BrO} / \mathrm{SO}_{2}$ in the plume of Nyiragongo in comparison to Etna, J. Geophys. Res.-Atmos., 120, 277-291, https://doi.org/10.1002/2013JD021069, 2015.

Bracher, A., Lamsal, L. N., Weber, M., Bramstedt, K., ColdeweyEgbers, M., and Burrows, J. P.: Global satellite validation of SCIAMACHY $\mathrm{O}_{3}$ columns with GOME WFDOAS, Atmos. Chem. Phys., 5, 2357-2368, https://doi.org/10.5194/acp-5-23572005, 2005.

Buchwitz, M., Rozanov, V. V., and Burrows, J. P.: A near-infrared optimized DOAS method for the fast global retrieval of atmospheric $\mathrm{CH}_{4}, \mathrm{CO}, \mathrm{CO}_{2}, \mathrm{H}_{2} \mathrm{O}$, and $\mathrm{N}_{2} \mathrm{O}$ total column amounts from SCIAMACHY Envisat-1 nadir radiances, J. Geophys. Res., D105, 15231-15245, 2000.

Burd, J. A., Peterson, P. K., Nghiem, S. V., Perovich, D. K., and Simpson, W. R.: Snowmelt onset hinders bromine monoxide heterogeneous recycling in the Arctic, J. Geophys. Res.-Atmos., 122, 8297-8309, 2017.

Burrows, J. P. and Chance, K. V.: Scanning Imaging Absorption Spectrometer for Atmospheric ChartographY, Proc. SPIE, Future European and Japanese Remote Sensing Sensors and Programs, 1490 146-154, 1991. 
Caspar, C. and Chance, K.: GOME wavelength calibration using solar and atmospheric spectra, in: Third ERS Symposium on Space at the service of our Environment, edited by: Guyenne, T.-D. and Danesy, D., ESA Special Publication, 414, 609, 1997.

Chance, K.: Analysis of $\mathrm{BrO}$ measurements from the Global Ozone Monitoring Experiment, Geophys. Res. Lett., 25, 3335-3338, 1998.

Chance, K.: Spectroscopic Measurements of Tropospheric Composition from Satellite Measurements in the Ultraviolet and Visible: Steps Toward Continuous Pollution Monitoring from Space, in: Remote Sensing of the Atmosphere for Environmental Security, edited by: Perrin, A., Ben Sari-Zizi, N., and Demaison, J., NATO Security through Science Series, ISBN 1-4020-5089-5, Springer, the Netherlands, pp. 1-25, 2006.

Chance, K.: OMI/Aura Bromine Monoxide (BrO) Total Column 1-orbit L2 Swath $13 \times 24 \mathrm{~km} \mathrm{V003,} \mathrm{Greenbelt,} \mathrm{MD,}$ USA, Goddard Earth Sciences Data and Information Services Center (GES DISC), last access: 20 November 2017, https://doi.org/10.5067/Aura/OMI/DATA2006, 2007.

Chance, K. and Kurucz, R.: An improved high-resolution solar reference spectrum for earth's atmosphere measurements in the ultraviolet, visible, and near infrared, J. Quant. Spectrosc. Ra., 111, 1289-1295, https://doi.org/10.1016/j.jqsrt.2010.01.036, 2010.

Chance, K. and Orphal, J.: Revised ultraviolet absorption cross sections of $\mathrm{H}_{2} \mathrm{CO}$ for the HITRAN database, J. Quant. Spectrosc. Ra., 112, 1509-1510, https://doi.org/10.1016/j.jqsrt.2011.02.002, 2011.

Chance, K., Palmer, P. I., Spurr, R. J. D., Martin, R. V., Kurosu, T. P., and Jacob, D. J.: Satellite observations of formaldehyde over North America from GOME, Geophys. Res. Lett., 27, 34613464, https://doi.org/10.1029/2000GL011857, 2000.

Chance, K., Kurosu, T. P., and Sioris, C. E.: Undersampling correction for array-detector based satellite spectrometers, Appl. Optics, 44, 1296-1304, 2005.

Chance, K. V. and Spurr, R. J. D.: Ring effect studies: Rayleigh scattering, including molecular parameters for rotational Raman scattering, and the Fraunhofer spectrum, Appl. Optics, 36, 52245230, https://doi.org/10.1364/AO.36.005224, 1997.

Chance, K. V., Burrows, J. P., and Schneider, W.: Retrieval and molecule sensitivity studies for the Global Ozone Monitoring Experiment and the SCanning Imaging Absorption spectroMeter for Atmospheric CHartographY, Proc. SPIE, Remote Sensing of Atmospheric Chemistry, 1491, 151-165, 1991.

Chan Miller, C., Gonzalez Abad, G., Wang, H., Liu, X., Kurosu, T., Jacob, D. J., and Chance, K.: Glyoxal retrieval from the Ozone Monitoring Instrument, Atmos. Meas. Tech., 7, 38913907, https://doi.org/10.5194/amt-7-3891-2014, 2014.

Chan Miller, C., Jacob, D. J., González Abad, G., and Chance, K.: Hotspot of glyoxal over the Pearl River delta seen from the OMI satellite instrument: implications for emissions of aromatic hydrocarbons, Atmos. Chem. Phys., 16, 4631-4639, https://doi.org/10.5194/acp-16-4631-2016, 2016.

Choi, S., Wang, Y., Salawitch, R. J., Canty, T., Joiner, J., Zeng, T., Kurosu, T. P., Chance, K., Richter, A., Huey, L. G., Liao, J., Neuman, J. A., Nowak, J. B., Dibb, J. E., Weinheimer, A. J., Diskin, G., Ryerson, T. B., da Silva, A., Curry, J., Kinnison, D., Tilmes, S., and Levelt, P. F.: Analysis of satellite-derived Arctic tropospheric $\mathrm{BrO}$ columns in conjunction with aircraft measurements during ARCTAS and ARCPAC, Atmos. Chem. Phys., 12, 12551285, https://doi.org/10.5194/acp-12-1255-2012, 2012.

Coldewey-Egbers, M., Weber, M., Lamsal, L. N., de Beek, R., Buchwitz, M., and Burrows, J. P.: Total ozone retrieval from GOME UV spectral data using the weighting function DOAS approach, Atmos. Chem. Phys., 5, 1015-1025, https://doi.org/10.5194/acp-5-1015-2005, 2005.

De Smedt, I., Stavrakou, T., Hendrick, F., Danckaert, T., Vlemmix, T., Pinardi, G., Theys, N., Lerot, C., Gielen, C., Vigouroux, C., Hermans, C., Fayt, C., Veefkind, P., Müller, J.-F., and Van Roozendael, M.: Diurnal, seasonal and long-term variations of global formaldehyde columns inferred from combined OMI and GOME-2 observations, Atmos. Chem. Phys., 15, 12519-12545, https://doi.org/10.5194/acp-15-12519-2015, 2015.

Dirksen, R., Dobber, M., Voors, R., and Levelt, P.: Prelaunch characterization of the Ozone Monitoring Instrument transfer function in the spectral domain, Appl. Optics, 45, 3972-3981, 2006.

Dobber, M.: OMI/Aura Level 1B UV Global Geolocated Earthshine Radiances 1-orbit L2 Swath $13 \times 24 \mathrm{~km}$ V003, Greenbelt, MD, USA, Goddard Earth Sciences Data and Information Services Center (GES DISC), last access: 31 March 2017, https://doi.org/10.5067/Aura/OMI/DATA1002, 2007.

Fleischmann, O. C., Hartmann, M., Burrows, J. P., and Orphal, J.: New ultraviolet absorption cross sections of $\mathrm{BrO}$ at atmospheric temperatures measured by time-windowing Fourier transform spectroscopy, J. Photochem. Photobiol. A., 168, 117132, https://doi.org/10.1016/j.jphotochem.2004.03.026, 2004.

Frieß, U., Sihler, H., Sander, R., PöHler, D., Yilmaz, S., and Platt, U.: The vertical distribution of $\mathrm{BrO}$ and aerosols in the Arctic: Measurements by active and passive differential optical absorption spectroscopy, J. Geophys. Res., 116, D00R04, https://doi.org/10.1029/2011JD015938, 2011.

González Abad, G., Liu, X., Chance, K., Wang, H., Kurosu, T. P., and Suleiman, R.: Updated Smithsonian Astrophysical Observatory Ozone Monitoring Instrument (SAO OMI) formaldehyde retrieval, Atmos. Meas. Tech., 8, 19-32, https://doi.org/10.5194/amt-8-19-2015, 2015.

Greenblatt, G. D., Orlando, J. J., Burkholder, J. B., and Ravishankara, A. R.: Absorption measurements of oxygen between 330 and 1140 nm, J. Geophys. Res., 95, 18577-18582, 1990.

Hausmann, M. and Platt, U.: Spectroscopic measurement of bromine oxide and ozone in the high Arctic during Polar Sunrise Experiment 1992, J. Geophys. Res., D12, 25399-25413, 1994.

Hebestreit, K., Stutz, J., Rosen, D., Matveiv, V., Peleg, M., Luria, M., and Platt, U.: DOAS Measurements of Tropospheric Bromine Oxide in Mid-Latitudes, Science, 283, 5398, https://doi.org/10.1126/science.283.5398.55, 1999.

Hegels, E., Crutzen, P. J., Klüpfel, T., Perner, D., and Burrows, J. P.: Global distribution of atmospheric bromine-monoxide from GOME on earth observing satellite ERS-2, Geophys. Res. Lett., 25, L3127, https://doi.org/10.1029/98GL02417, 1998.

Hendrick, F., Van Roozendael, M., Chipperfield, M. P., Dorf, M., Goutail, F., Yang, X., Fayt, C., Hermans, C., Pfeilsticker, K., Pommereau, J.-P., Pyle, J. A., Theys, N., and De Mazière, M.: Retrieval of stratospheric and tropospheric $\mathrm{BrO}$ profiles and columns using ground-based zenith-sky DOAS observations at Harestua, $60^{\circ} \mathrm{N}$, Atmos. Chem. Phys., 7, 4869-4885, https://doi.org/10.5194/acp-7-4869-2007, 2007. 
Hendrick, F., Rozanov, A., Johnston, P. V., Bovensmann, H., De Mazière, M., Fayt, C., Hermans, C., Kreher, K., Lotz, W., Sinnhuber, B.-M., Theys, N., Thomas, A., Burrows, J. P., and Van Roozendael, M.: Multi-year comparison of stratospheric BrO vertical profiles retrieved from SCIAMACHY limb and groundbased UV-visible measurements, Atmos. Meas. Tech., 2, 273285, https://doi.org/10.5194/amt-2-273-2009, 2009.

Hermans, C., Vandaele, A. C., Carleer, M., Fally, S., Colin, R., Jenouvrier, A., Coquart, B., and Mérienne, M.-F.: Absorption cross-sections of atmospheric constituents: $\mathrm{NO}_{2}, \mathrm{O}_{2}$, and $\mathrm{H}_{2} \mathrm{O}$, Environ. Sci. Pollut. Res., 6, 151-158, 1999.

Hermans, C., Vandaele, A. C., and Fally, S.: Fourier transform measurements of $\mathrm{SO}_{2}$ absorption cross sections: I. Temperature dependence in the $24000-29000 \mathrm{~cm}^{-1}(345-420 \mathrm{~nm})$ region, $\mathrm{J}$. Quant. Spectrosc. Ra., 110, 756-765, 2009.

Holla, R., Schmitt, S., Frieß, U., Pöhler, D., Zingler, J., Corsmeier, U., and Platt, U.: Vertical distribution of $\mathrm{BrO}$ in the boundary layer at the Dead Sea, Environ. Chem., 12, 438-460, https://doi.org/10.1071/EN14224, 2015.

Hollwedel, J., Wenig, M., Beirle, S., Kraus, S., Kühl, S., WilmsGrabe, W., Platt, U., and Wagner, T.: Year-to-year variations of spring time polar tropospheric $\mathrm{BrO}$ as seen by GOME, Adv. Space Res., 34, 804-808, 2004.

Hörmann, C., Sihler, H., Bobrowski, N., Beirle, S., Penning de Vries, M., Platt, U., and Wagner, T.: Systematic investigation of bromine monoxide in volcanic plumes from space by using the GOME-2 instrument, Atmos. Chem. Phys., 13, 4749-4781, https://doi.org/10.5194/acp-13-4749-2013, 2013.

Hörmann, C., Sihler, H., Beirle, S., Penning de Vries, M., Platt, U., and Wagner, T.: Seasonal variation of tropospheric bromine monoxide over the Rann of Kutch salt marsh seen from space, Atmos. Chem. Phys., 16, 13015-13034, https://doi.org/10.5194/acp-16-13015-2016, 2016.

Huang, G., Liu, X., Chance, K., Yang, K., Bhartia, P. K., Cai, Z., Allaart, M., Ancellet, G., Calpini, B., Coetzee, G. J. R., CuevasAgulló, E., Cupeiro, M., De Backer, H., Dubey, M. K., Fuelberg, H. E., Fujiwara, M., Godin-Beekmann, S., Hall, T. J., Johnson, B., Joseph, E., Kivi, R., Kois, B., Komala, N., König-Langlo, G., Laneve, G., Leblanc, T., Marchand, M., Minschwaner, K. R., Morris, G., Newchurch, M. J., Ogino, S.-Y., Ohkawara, N., Piters, A. J. M., Posny, F., Querel, R., Scheele, R., Schmidlin, F. J., Schnell, R. C., Schrems, O., Selkirk, H., Shiotani, M., Skrivánková, P., Stübi, R., Taha, G., Tarasick, D. W., Thompson, A. M., Thouret, V., Tully, M. B., Van Malderen, R., Vömel, H., von der Gathen, P., Witte, J. C., and Yela, M.: Validation of 10-year SAO OMI Ozone Profile (PROFOZ) product using ozonesonde observations, Atmos. Meas. Tech., 10, 2455-2475, https://doi.org/10.5194/amt-10-2455-2017, 2017.

Huang, G., Liu, X., Chance, K., Yang, K., and Cai, Z.: Validation of 10-year SAO OMI ozone profile (PROFOZ) product using Aura MLS measurements, Atmos. Meas. Tech., 11, 17-32, https://doi.org/10.5194/amt-11-17-2018, 2018.

Kleipool, Q. L., Dobber, M. R., de Haan, J. F., and Levelt, P. F.: Earth surface reflectance climatology from 3 years of OMI data, J. Geophys. Res., 113, D18308, https://doi.org/10.1029/2008JD010290, 2008.

Kromminga, H., Voigt, S., Orphal, J., and Burrows, J. P.: The temperature dependence $(213-293 \mathrm{~K})$ of the absorption crosssections of $\mathrm{OClO}$ in the $340-450 \mathrm{~nm}$ region measured by Fourier- transform spectroscopy, J. Photochem. Photobiol. A, 157, 149160, 2003.

Kroon, M., de Haan, J. F., Veefkind, J. P., Froidevaux, L., Wang, R., Kivi, R., and Hakkarainen, J. J.: Validation of operational ozone profiles from the Ozone Monitoring Instrument, J. Geophys. Res., 116, D18305, https://doi.org/10.1029/2010JD015100, 2011.

Kühl, S., Pukite, J., Deutschmann, T., Platt, U., and Wagner, T.: SCIAMACHY limb measurements of $\mathrm{NO}_{2}, \mathrm{BrO}$ and OClO. Retrieval of vertical profiles: algorithm, first results, sensitivity and comparison studies, Adv. Space Res., 42, 1747-1764, 2008.

Kurosu, T. P., Chance, K., and Sioris, C. E.: Preliminary results for $\mathrm{HCHO}$ and $\mathrm{BrO}$ from the EOS-Aura Ozone Monitoring Instrument, in: Proc. SPIE 5652, Passive Optical Remote Sensing of the Atmosphere and Clouds IV, 5652, 116-123, https://doi.org/10.1117/12.578606, 2004.

Lampel, J., Zielcke, J., Schmitt, S., Pöhler, D., Frieß, U., Platt, U., and Wagner, T.: Detection of $\mathrm{O} 4$ absorption around 328 and $419 \mathrm{~nm}$ in measured atmospheric absorption spectra, Atmos. Chem. Phys., 18, 1671-1683, https://doi.org/10.5194/acp18-1671-2018, 2018.

Lee, C., Richter, A., Weber, M., and Burrows, J. P.: $\mathrm{SO}_{2}$ Retrieval from SCIAMACHY using the Weighting Function DOAS (WFDOAS) technique: comparison with Standard DOAS retrieval, Atmos. Chem. Phys., 8, 6137-6145, https://doi.org/10.5194/acp8-6137-2008, 2008.

Levelt, P. F., van den Oord, G. H. J., Dobber, M. R., Mälkki, A., Visser, H., de Vries, J., Stammes, P., Lundell, J., and Saari, H.: The Ozone Monitoring Instrument, IEEE T. Geosci. Remote, 44, 1093-1101, https://doi.org/10.1109/TGRS.2006.872333, 2006.

Li, C., Joiner, J., Krotkov, N. A., and Bhartia, P. K.: A fast and sensitive new satellite $\mathrm{SO}_{2}$ retrieval algorithm based on principal component analysis: Application to the ozone monitoring instrument, Geophys. Res. Lett., 40, 6314-6318, https://doi.org/10.1002/2013GL058134, 2013.

Liao, J., Sihler, H., Huey, L. G., Neuman, J. A., Tanner, D. J., Friess, U., Platt, U., Flocke, F. M., Orlando, J. J., Shepson, P. B., Beine, H. J., Weinheimer, A. J., Sjostedt, S. J., Nowak, J. B., Knapp, D. J., Staebler, R. M., Zheng, W., Sander, R., Hall, S. R., and Ullmann, K.: A comparison of Arctic BrO measurements by chemical ionization mass spectrometry and long path-differential optical absorption spectroscopy, J. Geophys. Res.-Atmos., 116, D00r02, https://doi.org/10.1029/2010jd014788, 2011.

Liao, J., Huey, L. G., Tanner, D. J., Flocke, F. M., Orlando, J. J., Neuman, J. A., Nowak, J. B., Weinheimer, A. J., Hall, S. R., Smith, J. N., Fried, A., Staebler, R. M., Wang, Y., Koo, J.-H., Cantrell, C. A., Weibring, P., Walega, J., Knapp, D. J., Shepson, P. B., and Stephens, C. R.: Observations of inorganic bromine $\left(\mathrm{HOBr}, \mathrm{BrO}\right.$, and $\left.\mathrm{Br}_{2}\right)$ speciation at Barrow, Alaska, in spring 2009, J. Geophys. Res.-Atmos., 117, D00R16, https://doi.org/10.1029/2011JD016641, 2012.

Lindström, P. and Wedin, P.- $\AA$.: Gauss-Newton Based Algorithms for Constrained Nonlinear Least Squares Problems, Tech. Rep. UMINF-901.87, University of Umeå, software and report available at: http://plato.asu.edu/sub/nonlsq.html (last access: 10 July 2017), 1987.

Liu, X., Bhartia, P. K., Chance, K., Spurr, R. J. D., and Kurosu, T. P.: Ozone profile retrievals from the Ozone Mon- 
itoring Instrument, Atmos. Chem. Phys., 10, 2521-2537, https://doi.org/10.5194/acp-10-2521-2010, 2010.

Malicet, J., Daumont, D., Charbonnier, J., Parisse, C., Chakir, A., and Brion, J.: Ozone UV spectroscopy. II. Absorption cross sections and temperature dependence, J. Atmos. Chem., 21, $263-$ 273, https://doi.org/10.1007/BF00696758, 1995.

Martin, R. V., Sioris, C. E., Chance, K., Ryerson, T. B., Bertram, T. H., Wooldridge, P. J., Cohen, R. C., Neuman, J. A., Swanson, A., and Flocke, F. M.: Evaluation of space-based constraints on global nitrogen oxide emissions with regional aircraft measurements over and downwind of eastern North America, J. Geophys. Res., 111, D15308, https://doi.org/10.1029/2005JD006680, 2006.

Matveev, V., Mordechai, P., Rosen, D., Tov-Alper, D. S., Hebestreit, K., Stutz, J., Platt, U., Blake, D., and Luria, M.: Bromine oxideozone interaction over the Dead Sea, J. Geophys. Res.-Atmos., 106, 10375-10387, 2001.

McLinden, C. A., Haley, C. S., and Sioris, C. E.: Diurnal effects in limb scatter observations, J. Geophys. Res., 111, D14302, https://doi.org/10.1029/2005JD006628, 2006.

OMI: Algorithm Theoretical Basis Document, Volume IV, OMI Trace Gas Algorithms, edited by: Chance, K., ATBD-OMI-04, Version 2.0, available at: http://projects.knmi.nl/omi/documents/ data/OMI_ATBD_Volume_4_V2.pdf (last access: 5 December 2008), 2002.

Peterson, P. K., Simpson, W. R., and Nghiem, S. V.: Variability of bromine monoxide at Barrow, Alaska, over four halogen activation (March-May) seasons and at two onice locations, J. Geophys. Res.-Atmos., 121, 1381-1396, https://doi.org/10.1002/2015JD024094, 2016.

Platt, U. and Wagner, T.: Satellite mapping of enhanced BrO concentrations in the troposphere, Nature, 395, 486-490, 1998.

Puķīe, J., Kühl, S., Deutschmann, T., Platt, U., and Wagner, T.: Extending differential optical absorption spectroscopy for limb measurements in the UV, Atmos. Meas. Tech., 3, 631-653, https://doi.org/10.5194/amt-3-631-2010, 2010.

Richter, A., Wittrock, F., Eisinger, M., and Burrows, J. P.: GOME observations of tropospheric $\mathrm{BrO}$ in northern hemispheric spring and summer 1997, Geophys. Res. Lett., 25, 2683-2686, 1998.

Richter, A., Begoin, M., Hilboll, A., and Burrows, J. P.: An improved $\mathrm{NO}_{2}$ retrieval for the GOME-2 satellite instrument, Atmos. Meas. Tech., 4, 1147-1159, https://doi.org/10.5194/amt-41147-2011, 2011.

Salawitch, R. J., Weinstein, D. K., Kovalenko, L. J., Sioris, C. E., Wennberg, P. O., Chance, K., Ko, M. K. W., and McLinden, C. A.: Sensitivity of ozone to bromine in the lower stratosphere, Geophys. Res. Lett., 32, L05811, https://doi.org/10.1029/2004GL021504, 2005.

Salawitch, R. J., Canty, T., Kurosu, T., Chance, K., Liang, Q., da Silva, A., Pawson, S., Nielsen, J. E., Rodriguez, J. M., Bhartia, P. K., Liu, X. L., Huey, G., Liao, J., Stickel, R. E., Tanner, D. J., Dibb, J. E., Simpson, W. R., Donohoue, D., Weinheimer, A., Flocke, F., Knapp, D., Montzka, D., Neuman, J. A., Nowak, J. B., Ryerson, T. B., Oltmans, S., Blake, D. R., Atlas, E. L., Kinnison, D. E., Tilmes, S., Pan, L. L., Hendrick, F., Van Roozendael, M., Kreher, K., Johnston, P. V., Gao, R. S., Johnson, B., Bui, T. P., Chen, G., Pierce, R. B., Crawford, J. H., and Jacob, D. J.: A new interpretation of total column
BrO during Arctic spring, Geophys. Res. Lett., 37, L21805, https://doi.org/10.1029/2010GL043798, 2010.

Schofield, R., Connor, B. J., Kreher, K., Johnston, P. V., and Rodgers, C. D.: The retrieval of profile and chemical information from groundbased UV-visible spectroscopic measurements, J. Quant. Spectrosc. Ra., 86, 115-131, 2004a.

Schofield, R., Kreher, K., Connor, B. J., Johnston, P. V., Thomas, A., Shooter, D., Chipperfield, M. P., Rodgers, C. D., and Mount, G. H.: Retrieved tropospheric and stratospheric BrO columns over Lauder, New Zealand, J. Geophys. Res., 109, D14304, https://doi.org/10.1029/2003JD004463, 2004b.

Schofield, R., Johnston, P. V., Thomas, A., Kreher, K., Connor, B. J., Wood, S., Shooter, D., Chipperfield, M. P., Richter, A., von Glasow, R., and Rodgers, C. D.: Tropospheric and stratospheric $\mathrm{BrO}$ columns over Arrival Heights, Antarctica, 2002, J. Geophys. Res., 111, D22310, https://doi.org/10.1029/2005JD007022, 2006.

Seo, S., Richter, A., Blechschmidt, A.-M., Bougoudis, I., and Burrows, J. P.: First high resolution BrO column retrievals from TROPOMI, Atmos. Meas. Tech. Discuss., https://doi.org/10.5194/amt-2018-365, in review, 2018.

Sihler, H., Platt, U., Beirle, S., Marbach, T., Kühl, S., Dörner, S., Verschaeve, J., Frieß, U., Pöhler, D., Vogel, L., Sander, R., and Wagner, T.: Tropospheric BrO column densities in the Arctic derived from satellite: retrieval and comparison to ground-based measurements, Atmos. Meas. Tech., 5, 27792807, https://doi.org/10.5194/amt-5-2779-2012, 2012.

Simpson, W. R., von Glasow, R., Riedel, K., Anderson, P., Ariya, P., Bottenheim, J., Burrows, J., Carpenter, L. J., Frieß, U., Goodsite, M. E., Heard, D., Hutterli, M., Jacobi, H.-W., Kaleschke, L., Neff, B., Plane, J., Platt, U., Richter, A., Roscoe, H., Sander, R., Shepson, P., Sodeau, J., Steffen, A., Wagner, T., and Wolff, E.: Halogens and their role in polar boundary-layer ozone depletion, Atmos. Chem. Phys., 7, 4375-4418, https://doi.org/10.5194/acp7-4375-2007, 2007.

Sioris, C. E., Kovalenko, L. J., McLinden, C. A., Salawitch, R. J., Van Roozendael, M., Goutail, F., Dorf M., Pfeilsticker, K., Chance, K., von Savigny, C., Liu, X., Kurosu, T. P., Pommereau, J.-P., Bosch, H., and Frerick, J.: Latitudinal and vertical distribution of bromine monoxide in the lower stratosphere from Scanning Imaging Absorption Spectrometer for Atmospheric Chartography limb scattering measurements, J. Geophys. Res., 111, D14301, https://doi.org/10.1029/2005JD006479, 2006.

Slijkhuis, S., von Bargen, A., Thomas, W., and Chance, K.: Calculation of undersampling correction spectra for DOAS spectral fitting, Proceedings of the European Symposium on Atmospheric Measurements from Space, ESA WPP-161, ISSN 1022-6656, 563-569, 1999.

Spurr, R. J. D.: VLIDORT: A linearized pseudo-spherical vector discrete ordinate radiative transfer code for forward model and retrieval studies in multilayer multiple scattering media, J. Quant. Spectrosc. Ra., 102, 316-342, https://doi.org/10.1016/j.jqsrt.2006.05.005, 2006.

Stutz, J., Ackermann, R., Fast, J. D., and Barrie, L.: Atmospheric reactive chlorine and bromine at the Great Salt Lake, Utah, Geophys. Res. Lett., 29, 1-18, https://doi.org/10.1029/2002GL014812, 2002.

Stutz, J., Thomas, J. L., Hurlock, S. C., Schneider, M., von Glasow, R., Piot, M., Gorham, K., Burkhart, J. F., Ziemba, L., Dibb, J. E., 
and Lefer, B. L.: Longpath DOAS observations of surface BrO at Summit, Greenland, Atmos. Chem. Phys., 11, 9899-9910, https://doi.org/10.5194/acp-11-9899-2011, 2011.

Tas, E., Peleg, M., Matveev, V., Zingler, J., and Luria, M.: Frequency and extent of bromine oxide formation over the Dead Sea, J. Geophys. Res., D11304, https://doi.org/10.1029/2004JD005665, 2005.

Theys, N., Van Roozendael, M., Dils, B., Hendrick, F., Hao, N., and De Mazière, M.: First satellite detection of volcanic bromine monoxide emission after the Kasatochi eruption, Geophys. Res. Lett., 36, L03809, https://doi.org/10.1029/2008GL036552, 2009.

Theys, N., Van Roozendael, M., Hendrick, F., Yang, X., De Smedt, I., Richter, A., Begoin, M., Errera, Q., Johnston, P. V., Kreher, K., and De Mazière, M.: Global observations of tropospheric BrO columns using GOME-2 satellite data, Atmos. Chem. Phys., 11, 1791-1811, https://doi.org/10.5194/acp-11-1791-2011, 2011.

Toyota, K., McConnell, J. C., Lupu, A., Neary, L., McLinden, C. A., Richter, A., Kwok, R., Semeniuk, K., Kaminski, J. W., Gong, S.-L., Jarosz, J., Chipperfield, M. P., and Sioris, C. E.: Analysis of reactive bromine production and ozone depletion in the Arctic boundary layer using 3-D simulations with GEM-AQ: inference from synoptic-scale patterns, Atmos. Chem. Phys., 11, 3949-3979, https://doi.org/10.5194/acp-11-3949-2011, 2011.

Vandaele, A. C., Simon, P. C., Guilmot, J. M., Carleer, M., and Colin, R.: $\mathrm{SO}_{2}$ Absorption Cross Section measurement in the UV using a Fourier Transform Spectrometer. J. Geophys. Res., 99, 25599-25605, 1994.

Vandaele, A. C., Hermans, C., Simon, P. C., Carleer, M., Colin, R., Fally, S., Mérienne, M. F., Jenouvrier, A., and Coquart, B.: Measurements of the $\mathrm{NO}_{2}$ absorption cross sections from $42000 \mathrm{~cm}^{-1}$ to $10000 \mathrm{~cm}^{-1}(238-1000 \mathrm{~nm})$ at $220 \mathrm{~K}$ and 294 K, J. Quant. Spectrosc. Ra., 59, 171-184, 1998.

Vandaele, A. C., Hermans, C., and Fally, S.: Fourier Transform measurements of $\mathrm{SO}_{2}$ absorption cross sections: II. Temperature dependence in the $29000-44000 \mathrm{~cm}^{-1}(227-345 \mathrm{~nm})$ region, J. Quant. Spectrosc. Ra., 110, 2115-2126, 2009.
Veihelmann, B. and Kleipool, Q.: Reducing Along-Track Stripes in OMI-Level 2 Products, TN-OMIE-KNMI-785, 24 pp., 2006.

Vogel, L., Sihler, H., Lampel, J., Wagner, T., and Platt, U.: Retrieval interval mapping: a tool to visualize the impact of the spectral retrieval range on differential optical absorption spectroscopy evaluations, Atmos. Meas. Tech., 6, 275-299, https://doi.org/10.5194/amt-6-275-2013, 2013.

von Glasow, R., von Kuhlmann, R., Lawrence, M. G., Platt, U., and Crutzen, P. J.: Impact of reactive bromine chemistry in the troposphere, Atmos. Chem. Phys., 4, 2481-2497, https://doi.org/10.5194/acp-4-2481-2004, 2004.

Wang, H., Liu, X., Chance, K., González Abad, G., and Chan Miller, C.: Water vapor retrieval from OMI visible spectra, Atmos. Meas. Tech., 7, 1901-1913, https://doi.org/10.5194/amt-71901-2014, 2014.

Wang, H., Gonzalez Abad, G., Liu, X., and Chance, K.: Validation and update of OMI Total Column Water Vapor product, Atmos. Chem. Phys., 16, 11379-11393, https://doi.org/10.5194/acp-1611379-2016, 2016.

Weber, M., Lamsal, L. N., Coldewey-Egbers, M., Bramstedt, K., and Burrows, J. P.: Pole-to-pole validation of GOME WFDOAS total ozone with groundbased data, Atmos. Chem. Phys., 5, 1341-1355, https://doi.org/10.5194/acp-5-1341-2005, 2005.

Wilmouth, D. M., Hanisco, T. F., Donahue, N. M., and Anderson, J. G.: Fourier transform ultraviolet spectroscopy of the $A^{2} \Pi_{3 / 2} \leftarrow$ $X^{2} \Pi_{3 / 2}$ transition of BrO, J. Phys. Chem. A, 103, 8935-8945, 1999.

Yung, Y. L., Pinto, J. P., Watson, R. T., and Sander, S. P.: Atmospheric bromine and ozone perturbations in the lower stratosphere, J. Atmos. Sci., 37, 339-353, 1980.

Zhao, X., Strong, K., Adams, C., Schofield, R., Yang, X., Richter, A., Friess, U., Blechschmidt, A.-M., and Koo, J.-H.: A case study of a transported bromine explosion event in the Canadian high arctic, J. Geophys. Res.-Atmos., 121, 457-477, https://doi.org/10.1002/2015JD023711, 2015. 